\title{
Estimation of soil organic carbon stocks of two cities, New York City and Paris
}

\author{
Aurélie Cambou a,b,h, Richard K. Shaw ${ }^{\mathrm{c}}$, Hermine Huot ${ }^{\mathrm{d}, \mathrm{e}}$, Laure Vidal-Beaudet ${ }^{\mathrm{a}, *}$, Gilles Hunault ${ }^{\mathrm{f}}$, \\ Patrice Cannavo ${ }^{a}$, François Nold ${ }^{g}$, Christophe Schwartz ${ }^{b}$ \\ a EPHor, IRSTV, AGROCAMPUS OUEST, 49045 Angers, France \\ ${ }^{\mathrm{b}}$ Université de Lorraine, Inra, Laboratoire Sols et Environnement, F-54000 Nancy, France \\ c United States Department of Agriculture, Natural Resources Conservation Service, Somerset, NJ 08873, USA \\ ' School of Environmental Science and Engineering, Sun Yat-sen University, Guangzhou 510275, People's Republic of China \\ e Department of Earth and Environmental Sciences, Brooklyn College of City University of New York, Brooklyn, NY 11210, USA \\ ${ }^{\mathrm{f}}$ Laboratoire HIFIH, UPRES EA 3859, SFR 4208, Université d'Angers, Institut de Biologie en Santé PBH-IRIS CHU, 4, Rue Larrey, 49933 Angers Cedex, France \\ ${ }^{g}$ Laboratory of Agronomy of the Paris City, Paris Green Space and Environmental Division (DEVE), Parc Floral - Pavillon 5 - Rond-Point de la Pyramide, 75012 Paris, France \\ ${ }^{\mathrm{h}}$ Agence de l'Environnement et de la Maîtrise de l'Energie (ADEME), 75015 Paris, France
}

\section{H I G H L I G H T S}

- Urban soils represent important pools of organic carbon.

- Two different soil organic carbon stock assessment methods with similar results

- Similar soil organic carbon citywide totals between New York City (NYC) and Paris

- Soil organic carbon stocks of NYC and Paris equivalent to those of non-urban soils
G R A P H I C A L A B S T R A C T
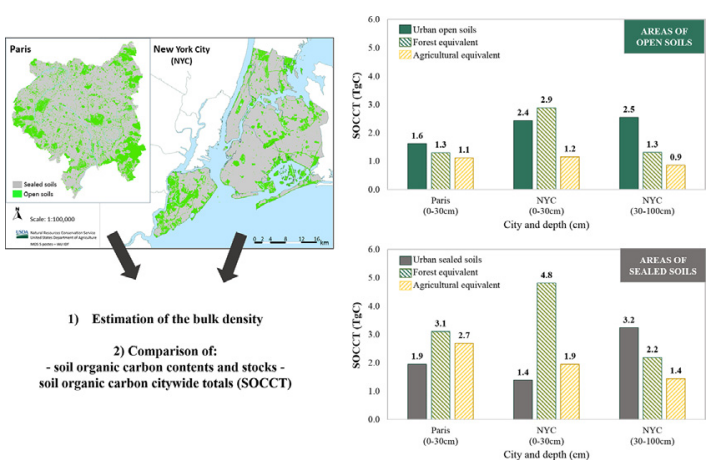

\section{A B S T R A C T}

In cities, the strong heterogeneity of soils, added to the lack of standardized assessment methods, serves as a barrier to the estimation of their soil organic carbon content (SOC), soil organic carbon stocks (SOCS; $\mathrm{kgC} \mathrm{m}^{-2}$ ) and soil organic carbon citywide totals (SOCCT; $\mathrm{kgC}$ ). Are urban soils, even the subsoils and sealed soils, contributing to the global stock of C? To address this question, the SOCS and SOCCT of two cities, New York City (NYC) and Paris, were compared. In NYC, soil samples were collected with a pedological standardized method to $1 \mathrm{~m}$ depth. The bulk density $\left(D_{\mathrm{b}}\right)$ was measured; SOC and SOCS were calculated for $0-30 \mathrm{~cm}$ and $30-100 \mathrm{~cm}$ depths in open (unsealed) soils and sealed soils. In Paris, the samples were collected for $0-30 \mathrm{~cm}$ depth in open soils and sealed soils by different sampling methods. If $\mathrm{SOC}$ was measured, $\mathrm{D}_{\mathrm{b}}$ had to be estimated using pedotransfer functions (PTFs) refitted from the literature on NYC data; hence, SOCS was estimated. Globally, SOCS for open soils were not significantly different between both cities (11.3 $\pm 11.5 \mathrm{kgC} \mathrm{m}^{-2}$ in NYC; $9.9 \pm 3.9 \mathrm{kgC} \mathrm{m}^{-2}$ in Paris). Nevertheless, SOCS was lower in sealed soils $\left(2.9 \pm 2.6 \mathrm{kgC} \mathrm{m}^{-2}\right.$ in NYC and $3.4 \pm 1.2 \mathrm{kgC} \mathrm{m}^{-2}$ in Paris $)$. The SOCCT was similar between both cities for $0-30 \mathrm{~cm}$ (3.8 TgC in NYC and $3.5 \mathrm{TgC}$ in Paris) and was also significant for the $30-100 \mathrm{~cm}$ layer in NYC (5.8 TgC). A comparison with estimated SOCCT in agricultural and forest soils demonstrated that the city's open soils represent important pools of organic carbon (respectively $110.4 \%$ and

\footnotetext{
* Corresponding author.

E-mail address: laure.beaudet@agrocampus-ouest.fr (L. Vidal-Beaudet).
} 
44.5\% more C in NYC and Paris than in agricultural soils, for 0-30 cm depth). That was mainly observable for the $1 \mathrm{~m}$ depth (146.6\% more C in NYC than in agricultural soils). The methodology to assess urban SOCS was also discussed.

\section{Introduction}

The increase of greenhouse gases, including $\mathrm{CO}_{2}$, in the atmosphere is responsible for the global warming. Moreover, recent anthropogenic emissions of greenhouse gases are higher than ever observed before (IPCC, 2014). In this context, soils appear to be a solution to mitigate climate change since they represent the largest terrestrial pool of organic carbon and they are in strong interaction with the atmosphere (Jacobson et al., 2000; Scharlemann et al., 2014). Indeed, they can indirectly provide the ecosystem service of regulation of the climate, behaving as a sink or a source of atmospheric $\mathrm{CO}_{2}$, according to different factors, such as land use (Dignac et al., 2017).

In that respect, soil organic carbon maintenance is a major issue. In this way, the recent " 4 per 1000 " initiative was launched at the COP21, to support states and non-governmental actors to allow for a better management of soils, for a long-term maintenance of soil organic carbon stocks (SOCS; $\mathrm{kgC} \mathrm{m}^{-2}$ ). However, the efforts are mainly focusing on cultivated and forested soils (http://4p1000.org; Minasny et al., 2017; Paustian et al., 2016). Nowadays, the Soils of Urban, Industrial, Traffic, Mining and Military Areas (SUITMAs) represent nearly 3\% of the world's territory. By 2030, as compared to the 2000s, the urban surface area alone is expected to increase by 1.2 million $\mathrm{km}^{2}$ worldwide, which represents $110 \mathrm{~km}^{2}$ a day (i.e. Paris city area; Morel et al., 2015; Seto et al., 2012). Since the 2000s, some initial attention has been paid to SOCS in urban soils. All over the world, research results have displayed a similar trend: in urban open (unsealed) soils, SOCS was generally higher than in agricultural soils, and could be in the same order of magnitude as the forest or grassland SOCS (Edmondson et al., 2012; Pouyat et al., 2009; Vasenev et al., 2014). However, the C stock estimation in cities should include the sealed soils, which represent a large part of highly human-altered areas (e.g., nearly 64\% in France in 2014; Service de la Statistique et de la Prospective, 2015). Thus, instead of SOCS, the soil organic carbon citywide totals (SOCCT, provided in mass units of carbon) should be estimated, to really understand the city's contribution to the Earth global stock of carbon and to be compared to nonurban soils (e.g., forest and agricultural soils). Three barriers limit this understanding: first, the sealed soils are very difficult to sample, because the sampling campaigns often have to be based on opportunities (tree planting, Raciti et al., 2012; reconstruction projects, Yan et al., 2015). Then, urban soils are globally very heterogeneous and SOCCT may depend on the city, in link with its history, culture, geography and geological background. Finally, there is not one standardized method to describe and characterize urban soils: for example, the depths studied in the literature are very heterogeneous, the sampling can be performed either per horizon or per depth, and even the formula to calculate SOCS is not harmonized (per horizon, Huot et al., 2017; at a given depth, Pouyat et al., 2009; different methods to calculate SOCS, Edmondson et al., 2012; Yan et al., 2015). Hence, the possibility to compare results between cities or even with non-urban soils is restricted.

This study focused on two cities, New York City (NYC) and Paris (more precisely, the Grand Paris Metropolis), in order to compare their soil organic carbon content (SOC), SOCS, and SOCCT. Similar surface areas and global population characterize these two major cities of the world, but they display a different climate. They are also very different in terms of their basement geology, history and urban management policies. In each city, a database of urban soil properties, including SOC, has been built since the 1990s, but with extremely different assessment methods. In Paris, the database displays at this time thousands of data points collected by different actors, following non-standardized methodology. Some important parameters, such as bulk density, which is a main parameter to calculate SOCS, are not available. On the contrary, the NYC database was created following a standardized and pedological approach, but includes a smaller amount of data. In both cities, most of the samples were collected from open soils, and only a few were from sealed soils; however, the latter were kept in this study, because of their importance to calculate SOCCT and the difficulty to sample them, leading to a paucity of data.

Hence, the first objective of the present study was to compare SOC of open soils between these two major cities, at a given point in time. The second objective was to assess SOCS and SOCCT in the urban open soils, but also in sealed soils, through the example of these two cities of western industrialized countries. Finally, a discussion about the limits resulting from these different methodological approaches was proposed.

\section{Materials and methods}

\subsection{New York City open soils}

\subsubsection{Study area}

New York City (NYC; $40^{\circ} 42^{\prime} 46^{\prime \prime} \mathrm{N} 74^{\circ} 00^{\prime} 21^{\prime \prime} \mathrm{W}$ ) is the most populated city in the United States with 8.5 million inhabitants in 2016 (U.S. Census Bureau). The city covers a land area of $772 \mathrm{~km}^{2}$, divided into five boroughs (Brooklyn, Bronx, Manhattan, Queens, and Staten Island), four of which are located on islands. The total population density is 10,756 inhabitants $\mathrm{km}^{-2}$. The elevation ranges from sea level to $122 \mathrm{~m}$. The climate in the area is humid continental (Dfa according to Köppen climate classification system) to humid subtropical within the city (Cfa), characterized by cold winters and hot and humid summers, with annual mean precipitation of $1270 \mathrm{~mm}$ and mean air temperature of $12.9^{\circ} \mathrm{C}$ (annual low and high temperatures: $+8.9{ }^{\circ} \mathrm{C}$ and $+16.8^{\circ} \mathrm{C}$ ). The NYC geomorphic setting includes three physiographic provinces: i) the crystalline bedrock (gneiss, schist, marble), which outcrops in Manhattan and the Bronx; ii) the Triassic and Jurassic sedimentary and igneous rocks in the northeastern part of Staten Island; and iii) the Atlantic coastal plain composed of unconsolidated deposits of late Cretaceous on Staten Island and Long Island (Brooklyn and Queens). Several glacial episodes deposited surficial materials for soil formation and shaped the landscape. Parent materials of NYC soils also include post-glacial deposits, such as tidal marsh deposits, organic materials and anthropogenic materials (NYC Soil Survey Staff, 2005).

By nature of its geography, the New York City has had limited room for expansion. Draining and filling of wetlands and extension of the shoreline have been common, often resulting in soils enriched in human artifacts and waste materials. The completion of the Erie Canal made the city the nation's commercial capital, and the population also grew rapidly during the 19 th century due to immigration. To address the increasing demand for green spaces, several parks were established, including a large central park in Manhattan (Central Park), completed in 1876, Prospect Park in Brooklyn in 1867, as well as several areas "of a rural character" in the Bronx in the 1880s (New York City Department of Parks and Recreation, n.d.). In addition to parkland, comprised of both active recreational and "natural" areas, the larger contiguous parcels of open space in the city include cemeteries and golf courses. 


\subsubsection{Open soils data/sampling method}

The soils of NYC have been mapped at a 1:12,000 scale by the USDANatural Resources Conservation Service following National Cooperative Soil Survey standards (USDA-NRCS). Soils formed in naturally deposited (ND) materials were differentiated from those formed in humanaltered and human-transported (HAHT) materials. The soil survey legend, available on the Web Soil Survey site (http://websoilsurvey.sc. egov.usda.gov/App/HomePage.htm), contains 236 map units composed of 37 soil series in ND materials, 29 soil series in HAHT materials, and six miscellaneous areas, including urban land covered by impervious surfaces, or sealed soils (62.7\% of land area citywide). The open soils formed in ND materials represent $8.6 \%$ of land area citywide and main parent materials are glacial till (4.6\% of the land area), tidal marsh (1.9\%) and marine sands (0.5\%). The open soils formed in HAHT materials represent $27.6 \%$ of land area citywide. Primary anthropogenic parent materials encompass loamy fill with low artifact $(<10 \%)$ content (14.9\% of the land area), construction debris or artifactual $(5.9 \%)$, dredged materials (3\%), domestic wastes (landfills; $1.6 \%$ ) and coal combustion ash $(0.1 \%)$.

For most of the soil series, one or more pedons were described by horizon to a depth of at least $100 \mathrm{~cm}$, except if the bedrock was reached within $100 \mathrm{~cm}$, following the USDA-NRCS criteria (Schoeneberger et al., 2012). For each pedon, all of the described horizons were sampled for physical, chemical, and mineralogical analyses. The mass and volume of coarse fragments (respectively $\delta_{<2 \mathrm{~mm}} \mathrm{~W} / \mathrm{w}$ and $\delta_{<2 \mathrm{~mm}} \mathrm{v} / \mathrm{v}$ ) $>20 \mathrm{~mm}$ were assessed in the field and the smaller coarse fragments (2-20 mm) were weighed in the laboratory. Clods were sampled to assess the bulk density after correction for coarse fragments (Soil Survey Staff, 2014). The database used for the estimation of C storage encompasses 58 pedons sampled between 1995 and 2015, all of which are representative of sampling sites larger than $2000 \mathrm{~m}^{2}$. In general, the soils, in their dominant land use and cover, were sampled for complete characterization for soil survey database population, although seven of the pedons were part of an urban soil carbon study. To allow for the estimation of citywide figures, five pedons from sites just outside of the city in New Jersey were included. The open soils studied in NYC were located in urban fallows (i.e. urban wastelands), urban woodlands, salt marshes, and parks.

\subsection{Paris open soils}

\subsubsection{Study area}

Paris is the capital of France ( $\left.48^{\circ} 51^{\prime} 12^{\prime \prime} \mathrm{N}, 2^{\circ} 20^{\prime} 55^{\prime \prime} \mathrm{E}\right)$. This city is included in the Grand Paris Metropolis, which is the urbanized centre of the region Ile-de-France. It covers an area of $815 \mathrm{~km}^{2}$ (Paris city covers $105 \mathrm{~km}^{2}$ ), including $17.4 \mathrm{~km}^{2}$ occupied by water. The population was 7.0 million inhabitants in 2014 (with nearly 2.22 million in Paris city) and the total population density was 8589 inhabitants $\mathrm{km}^{-2}$, but it was 21,067 inhabitants $\mathrm{km}^{-2}$ in Paris city. Finally, this region accounted for approximately $10.6 \%$ of the total population of metropolitan France (INSEE - French National Institute of Statistics and Economic Studies, 2014). The altitude is between $24 \mathrm{~m}$ and $180 \mathrm{~m}$. The natural parent material is sedimentary (Jurassic limestone, Oligocene green marl and clays, carbonaceous alluvial deposits, Oligocene quartz sand, Sparnacien). However, the backfills are commonly present in this city, where they can reach $10 \mathrm{~m}$ in depth and include various natural and technogenic materials (e.g., silt, stones, wood, rubble; Béchet et al., 2009). According to Köppen climate classification system, the climate is temperate oceanic $(\mathrm{Cfb})$ with an average temperature of $11.6^{\circ} \mathrm{C}$ (annual low and high temperatures: $+7.86^{\circ} \mathrm{C}$ and $+15.5^{\circ} \mathrm{C}$ ) and an average rainfall of $591 \mathrm{~mm}$ per year. During the 19th century, Paris city management was marked by the Haussmann period, which strongly transformed the city, according to three ideas: i) to have more space to clean up the city, ii) to unify the different districts and iii) to embellish the landscape with squares, parks and public promenades. Thus, during this period, $18.3 \mathrm{~km}^{2}$ of green spaces were created in Paris city.
However, Paris city was geographically limited by two walls and was becoming overcrowded. At the end of the 19th century, the first suburbs began to be urbanized and inhabited as well.

For the following, the term "Paris" corresponds to the Grand Paris Metropolis, including Paris city and its first suburbs.

\subsubsection{Paris open soils data}

To build the Paris database, available data from the Paris agronomic laboratory, which has been saving soil analyses since 1993, were used. The database contained nearly 10,000 samples mostly collected in urban areas of the Paris region. The sampling methods were not standardized as they depended on various projects of soil fertility assessment led by different organizations. Thus, the studied soil depths were not harmonized, but globally only the first layer of topsoil added during the site creation (or renovation) to support the vegetation was sampled, in order to manage its fertility. Then, the exact locations of the sampling points were sometimes not precisely known, and some parameters, such as bulk density, were not determined. To allow a comparison with NYC database, only the samples collected between 1995 and 2015, within a 0-30 cm depth, in parks, urban woodlands and urban garden areas (i.e., horticulture centres, shared or family gardens and housing accompaniments) of Paris, were selected. These three land uses (parks, woodlands, gardens) constituted the "open soils" category for Paris. If many sampling campaigns were launched on the same sampling site, only the samples collected during the most recent sampling campaign were selected for this location. Moreover, only the sampling sites larger than $2000 \mathrm{~m}^{2}$ were studied to allow a comparison with NYC sites. Thus, 593 samples of soils collected in open areas were finally kept to build the database of Paris used in this study.

\subsection{Sealed soils in both cities}

Few data from sealed soils were available in the Paris and NYC databases (seven and eight samples, respectively). In Paris, the exact depth of sampling was not known but was set to $30 \mathrm{~cm}$. In NYC, the thickness of asphalt and concrete layers were assessed and the underlying soil layer was described and sampled to a $100 \mathrm{~cm}$ depth, which was generally homogeneous. To allow for comparison, an average value of SOC was calculated for a $30-\mathrm{cm}$ thick layer of soil under the impervious surface as well as a $70-\mathrm{cm}$ thick layer of soil for NYC 30-100 cm dataset. The " $0-30 \mathrm{~cm}$ " studied depth in sealed soils concerns the $30 \mathrm{~cm}$ of soil under the impervious layers (the latter were not included in this thickness), such as in Wei et al. (2014a) or Yan et al. (2015). The 30-100 cm depth in sealed soils excluded the impervious layer thickness as well.

Finally, all the sampling site locations from both cities are indicated on the map in Fig. 1.

\subsection{Soil parameter analyses}

In NYC, the soil analyses were conducted at the Kellogg Soil Survey Laboratory (USDA-NRCS) following standardized methods (Soil Survey Staff, 2014). The samples were air-dried and sieved at $2 \mathrm{~mm}$. The soil total carbon content (totC) was measured by dry combustion. The carbonate content ( tot $\mathrm{CaCO}_{3}$ ) and the soil inorganic carbon content (SIC) were determined for non-acidic soils by treating the soil with $\mathrm{HCl}$ and measuring the evolved $\mathrm{CO}_{2}$ manometrically. The $\mathrm{SOC}$ was estimated by subtracting SIC from totC. For each pedon, a weighted average for each parameter was calculated for the surface $(0-30 \mathrm{~cm})$ and subsurface $(30-100 \mathrm{~cm})$ depths. These datasets are referred to as NYC $0-30 \mathrm{~cm}$ and NYC $30-100 \mathrm{~cm}$. The dataset NYC 30-100 cm contained only 56 samples, since two soils were too shallow to be taken into account. Four soils were $<100 \mathrm{~cm}$ deep and the average value was calculated for their depth.

In Paris, the soil samples were analysed using standardized methods by the Paris agronomic laboratory between 1995 and 2015. The samples were air-dried and sieved at $2 \mathrm{~mm}$ allowing to determine $\delta_{<2 \mathrm{~mm}} \mathrm{w} / \mathrm{w}$. 
Paris

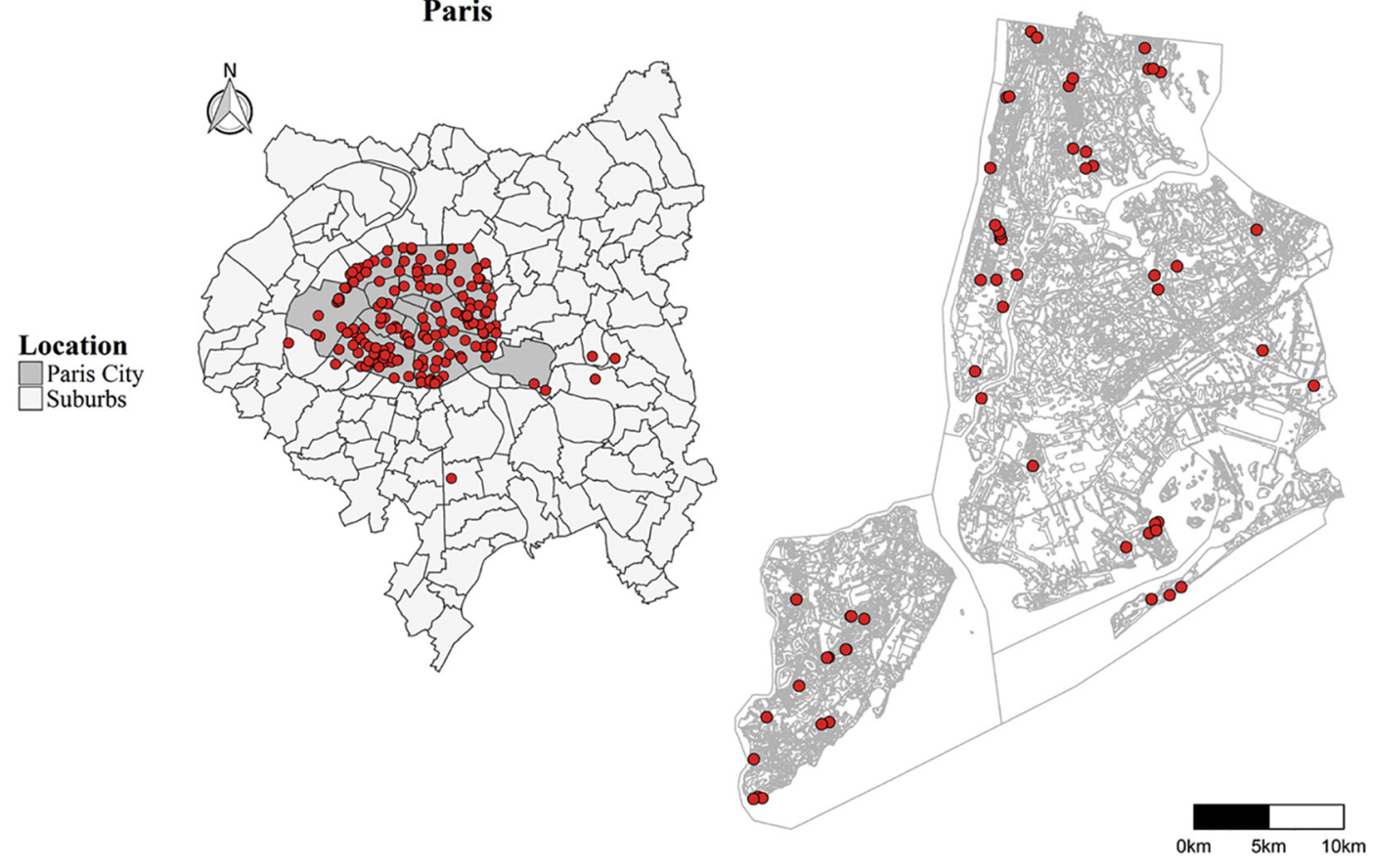

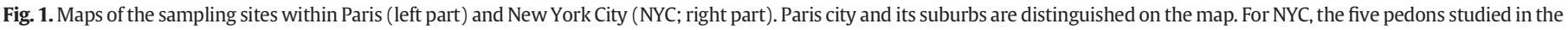
New Jersey area are not included.

The totC was analysed by sulfochromic oxidation until May 2015; then, it was carried out by dry combustion (AFNOR, 1995; ISO, 1998). The SIC (or totCaCO ${ }_{3}$ ) was determined by the volumetric method (AFNOR, 1999). The SOC was estimated by subtracting SIC from totC.

\subsection{SOCS calculation}

As shown by Poeplau et al. (2017), the method used to calculate SOCS can strongly impact the results. However, some estimation had to be proposed to calculate Paris and NYC SOCS with the same equation (Eq. (1)).

SOCS $=\sum_{1}^{\mathrm{n}} \operatorname{SOCi} \times \operatorname{DBi}\left(1-\frac{\delta 2 m m \frac{\mathrm{v}}{\mathrm{v}}}{100}\right) \times \mathrm{Hi}$

with $\mathrm{DBi}=\frac{\text { Mass }(\text { fine earth })}{\mathrm{V}(\text { sample })-\mathrm{V}(\text { coarse fraction })}$

where SOCS is the stock calculated in each studied depth $(0-30 \mathrm{~cm}$ or $30-100 \mathrm{~cm} ; \mathrm{kgC} \mathrm{m}^{-2}$ ); $\mathrm{SOC}_{\mathrm{i}}$ is soil organic carbon content of the horizon $\mathrm{i}\left(\mathrm{gC} \mathrm{kg}^{-1}\right)$. Then, $\mathrm{Db}_{\mathrm{i}}$ is the bulk density of the fine earth $\left(\mathrm{D}_{\mathrm{b}}\right)$ of the horizon $\mathrm{i}$, calculated as the fine earth mass divided by the difference of the total volume of the sample and the coarse fraction volume of the sample (Eq. (2); $\left.\mathrm{g} \mathrm{cm}^{-3}\right) ; \delta_{2 \mathrm{~mm}} \mathrm{v} / \mathrm{v}$ is the coarse fraction volumetric content (\%); $\mathrm{H}_{\mathrm{i}}$ is the thickness of the horizon $\mathrm{i}(\mathrm{m})$. Finally, $\mathrm{n}$ is the number of horizons of the soil profile included between 0 and $30 \mathrm{~cm}$ or 30 and $100 \mathrm{~cm}$.
For both datasets, an estimation of $\delta_{2 \mathrm{~mm}} \mathrm{v} / \mathrm{v}$ using $\delta_{2 \mathrm{~mm}} \mathrm{w} / \mathrm{w}(\%)$ was first performed as following USDA-NRCS (2003):

$\mathrm{z}=0.0056 \times \mathrm{y}^{2}+0.39 \times \mathrm{y}+2.03$

where $\mathrm{z}$ is $\delta_{2 \mathrm{~mm}} \mathrm{v} / \mathrm{v}(\%)$, and $\mathrm{y}, \delta_{2 \mathrm{~mm}} \mathrm{w} / \mathrm{w}(\%)$.

Unlike the soils in NYC, the soil samples in Paris were not collected per horizon, but only for a given depth. So, the parameters were considered as homogeneous for the first $30 \mathrm{~cm}$ in Paris selected values. Moreover, $D_{b}$ was not determined in Paris, contrary to most of NYC samples. Thus, different pedotransfer functions (PTFs) to estimate $D_{b}$ were tested on NYC data, using SOC (here, the $\mathrm{SOC}_{\mathrm{i}}$ and $\mathrm{Db}_{\mathrm{i}}$ were used, i.e., before calculating the weighted average SOC and $D_{b}$ for each depth). For this, several models were tested after being refitted from Chen et al. (2018), using also the Levenberg-Marquardt non-linear least-square method available in the minpack.lm R package (Elzhov et al., 2013). This work was conducted on two datasets: the first one included all the samples obtained by horizon in NYC $0-30 \mathrm{~cm}$ and the second included all the samples obtained by horizon in NYC 30-100 cm. Each dataset was split into two independent subsets (by avoiding separating the samples from a same pedon): the training subset was used to develop the model and the validation subset was used to test it. The Table 1 gives the descriptive statistics of SOC and $D_{b}$ in these two subsets, for NYC 0-30 cm and NYC 30-100 cm.

The model precision was analysed using the adjusted determination coefficient $\left(\mathrm{R}^{2}\right.$ adj $)$ and the root mean square prediction error (RMSPE) between the measured values and predicted values. The equation providing the $\mathrm{R}^{2}$ adj and the slope closest to a value of one, and the lowest RMSPE was selected. Thus, we estimated: i) the undetermined $D_{b}$ of NYC soil for both depths, using, the model selected in the $0-30 \mathrm{~cm}$ depth and the one selected in the $30-100 \mathrm{~cm}$ depth respectively; ii) the $D_{b}$ of all the samples of Paris database, using the model built with the NYC 0-30 cm dataset. 
Table 1

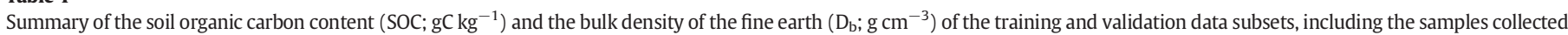
(N) per horizon in NYC 0-30 cm and NYC 30-100 cm; SD is the standard deviation.

\begin{tabular}{|c|c|c|c|c|c|c|c|c|c|c|c|c|c|}
\hline \multirow[t]{2}{*}{ Layer $(\mathrm{cm})$} & \multirow[b]{2}{*}{ Parameter } & \multicolumn{6}{|c|}{ Training data subset } & \multicolumn{6}{|c|}{ Validation data subset } \\
\hline & & $\mathrm{N}$ & Median & Mean & SD & Min & Max & $\mathrm{N}$ & Median & Mean & SD & Min & Max \\
\hline \multirow[t]{2}{*}{$0-30$} & SOC & 86 & 33.4 & 80.2 & 121.6 & 0.5 & 494.4 & 47 & 25.5 & 62.7 & 95.6 & 1.0 & 474.7 \\
\hline & $\mathrm{D}_{\mathrm{b}}$ & 86 & 1.3 & 1.2 & 0.5 & 0.1 & 1.9 & 47 & 1.3 & 1.1 & 0.5 & 0.2 & 1.7 \\
\hline \multirow[t]{2}{*}{$30-100$} & SOC & 100 & 6.8 & 50.6 & 115.3 & 0.0 & 624.3 & 44 & 3.4 & 13.1 & 24.0 & 0.2 & 89.0 \\
\hline & $\mathrm{D}_{\mathrm{b}}$ & 100 & 1.5 & 1.4 & 0.4 & 0.2 & 2.1 & 44 & 1.6 & 1.5 & 0.3 & 0.5 & 1.9 \\
\hline
\end{tabular}

Concerning the sealed soils, Eq. (3) was also used to estimate the coarse fraction volumetric percent in both Paris and NYC datasets. As to the $D_{b}$ estimation, the distribution of $D_{b}$ in NYC was very narrow and was similar to the $D_{b}$ measured on sealed soils by Yan et al. (2015). Because of this low distribution and the low amount of data for the sealed soils, developing a PTF was not possible, so the average NYC $D_{b}$ was used as $D_{b}$ for the sealed soils of Paris.

\subsection{Statistical analyses to study the factor effects}

The comparisons of SOC and SOCS between Paris and NYC 0-30 cm and between the two depths in NYC, at a given point in time, were performed using Kruskal-Wallis test on R software (significant level at $\mathrm{p}=$ 0.05; R Core Team, 2013). The same test allowed studying the effects of environmental factors on SOCS in each city for the same depth $(0-30 \mathrm{~cm})$ and it was followed by a Nemenyi posthoc test to distinguish the levels displaying significantly different values (PMCMR package; Pohlert, 2014). These non-parametrical tests were preferred since the normal distribution and the homoscedasticity were not validated for the datasets. The environmental factors studied included the following: the land use and the geographic location in Paris; the land use and the parent material type in NYC.

\subsection{Calculation of the soil organic carbon citywide totals}

The soil organic carbon citywide totals (SOCCT, $\mathrm{kgC}$ ) is the product of average SOCS $\left(\mathrm{kgC} \mathrm{m}^{-2}\right)$ and the surface area covered by the analysed soil $\left(\mathrm{m}^{2}\right)$. In NYC, this calculation was independently performed for each depth (at 0-30 cm and 30-100 cm) and for open soils and sealed soils. In Paris, the calculation was also performed independently for the open and sealed soils (at $0-30 \mathrm{~cm}$ ). Furthermore, in each city, the SOCCT of open soils was calculated according to the factors having a significant effect on SOCS (explained in Section 3.3).

To allow a comparison with regional soils, an estimation of equivalent SOCCT for forest and agricultural soils of NYC and Paris regions was carried out for the $0-30 \mathrm{~cm}$ depth (and for the 30-100 cm depth in NYC) and for the same areas. More precisely, the citywide surface areas of open spaces ( $289 \mathrm{~km}^{2}$ in NYC and $233 \mathrm{~km}^{2}$ in Paris) and of sealed soils (483 $\mathrm{km}^{2}$ in NYC and $565 \mathrm{~km}^{2}$ in Paris) were used. Then, for the estimation in NYC, the data of SOCS of the forest and agricultural soils of New Jersey (18 samples) analysed by USDA-NRCS (unpublished data) were used. At $0-30 \mathrm{~cm}$ depth, SOCS were $10.0 \mathrm{kgC} \mathrm{m}^{-2}$ and $4.0 \mathrm{kgC} \mathrm{m}^{-2}$, in forest and agricultural soils, respectively. At $30-100 \mathrm{~cm}$ depth, SOCS reached $4.5 \mathrm{kgC} \mathrm{m}^{-2}$ and $3.0 \mathrm{kgC} \mathrm{m}^{-2}$ in forest and in agricultural soils, respectively. For the estimation in Paris, the SOCS of forest and agricultural soils of its region (Ile-de-France) were obtained from the national monitoring network of soil quality "Réseau de Mesures de la Qualité des Sols" ( INRA, Unité INFOSOL, Orléans, 2017; Arrouays et al., 2002). In this region, SOCS was $5.6 \mathrm{kgC} \mathrm{m}^{-2}$ in forest soils ( 14 samples) and $4.8 \mathrm{kgC} \mathrm{m}^{-2}$ in agricultural soils (36 samples), for $0-30 \mathrm{~cm}$ depth.

\section{Results}

\subsection{Soil organic carbon content in open soils of both cities}

Globally, SOC in NYC soils was higher than in Paris soils, for the same depth. Moreover, in NYC, the topsoil SOC was higher than the subsoil one (Table 2). By comparing the SOC in woodlands between both cities, NYC 0-30 cm displayed a higher SOC than Paris. Both had a significantly higher SOC than the NYC $30-100 \mathrm{~cm}$ woodlands. However, in the parks, SOC was not significantly different between NYC $0-30 \mathrm{~cm}$ and Paris. The value in NYC 0-30 cm was still significantly higher than in NYC $30-100 \mathrm{~cm}$, but the difference was not as pronounced as in woodlands. The fallows were the only land use where SOC was not significantly different between NYC 0-30 cm and NYC 30-100 cm.

The variability of SOC distribution was very high in NYC compared to the one in Paris: for all the open soils together, the coefficient of variation $(\mathrm{CV})$ was equal to $56 \%$ for Paris $(0-30 \mathrm{~cm}), 159 \%$ for NYC $0-30 \mathrm{~cm}$ and $266 \%$ for NYC $30-100 \mathrm{~cm}$. This was principally due to the high CV observed in the fallows, in NYC (CV $=202 \%$ in the $0-30 \mathrm{~cm}$ of depth and $C V=217 \%$ in the $30-100 \mathrm{~cm}$ of depth). However, this difference of variability was not observed in $0-30 \mathrm{~cm}$ of depth, in parks: CV was equal to $55 \%$ in Paris and $59 \%$ in NYC $0-30 \mathrm{~cm}$. Since Paris SOC data were included within NYC 0-30 cm SOC range in open soils, it was then possible to build a PTF using NYC SOC data, in order to estimate $D_{b}$ in the Paris dataset.

Table 2

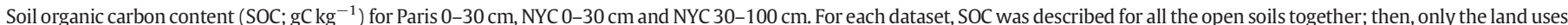

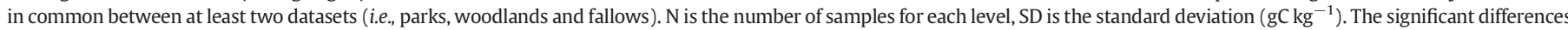

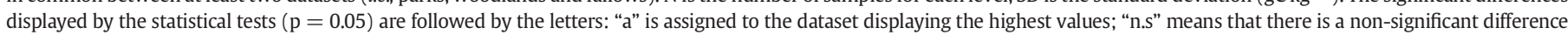

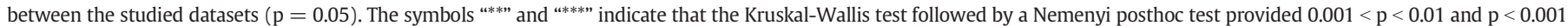
respectively.

\begin{tabular}{|c|c|c|c|c|c|c|c|c|c|c|c|c|c|c|c|c|c|c|}
\hline \multirow[t]{3}{*}{ Land use } & \multicolumn{6}{|c|}{ Paris } & \multicolumn{6}{|c|}{ NYC } & \multirow[b]{3}{*}{$\mathrm{N}$} & \multicolumn{5}{|l|}{ NYC } \\
\hline & \multicolumn{6}{|c|}{$0-30 \mathrm{~cm}$ depth } & \multicolumn{6}{|c|}{$0-30 \mathrm{~cm}$ depth } & & \multicolumn{5}{|c|}{$30-100 \mathrm{~cm}$ depth } \\
\hline & $\mathrm{N}$ & Median & Mean & SD & Min & $\operatorname{Max}$ & $\mathrm{N}$ & Median & Mean & SD & Min & Max & & Median & Mean & SD & Min & Max \\
\hline All open soils*** & 593 & 25.5 (b) & 28.4 & 16.0 & 2.3 & 143.9 & 58 & $34.0(a)$ & 63.3 & 100.9 & 0.8 & 560.5 & 56 & $5.6(c)$ & 38.2 & 101.3 & 0.3 & 533.3 \\
\hline Parks** & 547 & 26.1 (a) & 29.0 & 16.0 & 2.3 & 143.9 & 17 & 22.7 (a) & 30.0 & 17.7 & 9.6 & 77.9 & 16 & 8.1 (b) & 18.3 & 22.2 & 1.5 & 76.5 \\
\hline Woodlands ${ }^{* * *}$ & 16 & $18.6(\mathrm{~b})$ & 20.4 & 12.1 & 4.9 & 42.3 & 22 & $42.6(a)$ & 51.0 & 26.4 & 10.6 & 106.7 & 21 & $3.1(\mathrm{c})$ & 4.1 & 2.8 & 1.0 & 10.6 \\
\hline Fallows & - & - & - & - & - & - & 15 & 9.5 (n.s) & 88.6 & 179.1 & 0.8 & 560.5 & 15 & 6.1 & 82.1 & 178.4 & 0.3 & 533.3 \\
\hline
\end{tabular}


Table 3

Summary of the pedotransfer functions developed in the study to estimate the bulk density of the fine earth $\left(\mathrm{D}_{\mathrm{b}} ; \mathrm{g} \mathrm{cm}^{-3}\right)$; $\mathrm{X}$ is the soil organic carbon content expressed in $\mathrm{g}$ $100 \mathrm{~g}^{-1}$. For each layer, the line written in bold corresponds to the model chosen for the following estimations of $\mathrm{D}_{\mathrm{b}}$.

\begin{tabular}{llllll}
\hline Layer $(\mathrm{cm})$ & Model & Function & \multicolumn{2}{l}{ Coefficients } \\
\cline { 4 - 6 } & & & $\mathrm{a}$ & $\mathrm{b}$ & $\mathrm{c}$ \\
\hline \multirow{2}{*}{$0-30$} & $\mathrm{~A}$ & $\mathrm{a} \times \mathrm{e}^{(\mathrm{b} \times \mathrm{X})}+\mathrm{c}$ & 1.3 & -0.1 & 0.3 \\
\multirow{2}{*}{$30-100$} & $\mathrm{~B}$ & $(\mathrm{a} \times \mathrm{X}+\mathrm{b})^{-1}$ & $6.2 \times 10^{-2}$ & 0.6 & - \\
& $\mathrm{A}$ & $\mathrm{a} \times \mathrm{e}^{(\mathrm{b} \times \mathrm{X})}+\mathrm{c}$ & 1.1 & -0.1 & 0.6 \\
& $\mathrm{~B}$ & $(\mathrm{a} \times \mathrm{X}+\mathrm{b})^{-1}$ & $4.7 \times 10^{-2}$ & 0.6 & - \\
\hline
\end{tabular}

3.2. Estimation and comparison of organic carbon stock per unit area in open soils

\subsubsection{Estimation of the bulk density}

The refitted coefficients for the PTFs are listed in Table 3 for NYC 0-30 cm and NYC 30-100 cm: only the two best models tested on NYC data are shown.

In NYC 0-30 cm, both models were efficient: with the model $A, \mathrm{R}^{2}$ adj reached 0.79 , the slope was 0.75 , and the RMSPE was $0.22 \mathrm{~g} \mathrm{~cm}^{-3}$; with the model $\mathrm{B}, \mathrm{R}^{2}$ adj was 0.80 , the slope was 0.73 , and the RMSPE was $0.22 \mathrm{~g} \mathrm{~cm}^{-3}$ (Fig. 2).

In NYC 30-100 cm, the models were both less efficient: with the model $\mathrm{A}, \mathrm{R}^{2}$ adj was 0.66 , the slope was 0.53 , and the RMSPE was $0.20 \mathrm{~g} \mathrm{~cm}^{-3}$; with the model B, $\mathrm{R}_{\text {adj }}^{2}$ was 0.66 , the slope was 0.47 , and the RMSPE was $0.21 \mathrm{~g} \mathrm{~cm}^{-3}$. As the model A provided the best predictions for NYC $30-100 \mathrm{~cm}$, and was similar to the model B for NYC 0-30 cm, it was chosen for both depths to estimate the unknown $D_{\mathrm{b}}$.

The bulk density was not significantly different between Paris and NYC 0-30 cm, for all open soils together (data not shown). Estimated average $D_{\mathrm{b}}$ was $1.3 \pm 0.2 \mathrm{~g} \mathrm{~cm}^{-3}\left(\min =0.6 \mathrm{~g} \mathrm{~cm}^{-3} ; \max =\right.$ $1.6 \mathrm{~g} \mathrm{~cm}^{-3}$ ) in Paris, and average $\mathrm{D}_{\mathrm{b}}$ was $1.2 \pm 0.3 \mathrm{~g} \mathrm{~cm}^{-3}$ ( $\min =$ $0.2 \mathrm{~g} \mathrm{~cm}^{-3}$; $\max =1.7 \mathrm{~g} \mathrm{~cm}^{-3}$ ) in NYC 0-30 cm. However, $\mathrm{D}_{\mathrm{b}}$ was significantly higher in NYC 30-100 cm, with a mean equal to $1.4 \pm$ $0.4 \mathrm{~g} \mathrm{~cm}^{-3}\left(\min =0.2 \mathrm{~g} \mathrm{~cm}^{-3} ; \max =1.9 \mathrm{~g} \mathrm{~cm}^{-3}\right)$.

\subsubsection{Comparison of SOCS between Paris, New York City and their regional} soils

The values of SOCS were not significantly different in topsoils $\left(0-30 \mathrm{~cm}\right.$ ) between Paris (mean $9.9 \pm 3.9 \mathrm{kgC} \mathrm{m}^{-2}$ ) and NYC (mean $11.3 \pm 11.5 \mathrm{kgC} \mathrm{m}^{-2}$; Fig. 3). The SOCS values in subsurface soils (30-100 cm) in NYC were significantly lower, even if the mean was $14.5 \pm 34.7 \mathrm{kgC} \mathrm{m}^{-2}$. Indeed, as for SOC, this high mean was explained by some very high SOCS values (maximum SOCS $=216.3 \mathrm{kgC} \mathrm{m}^{-2}$ ), but the SOCS median was much lower in NYC $30-100 \mathrm{~cm}$ than in NYC 0-30 cm and Paris (SOCS median was respectively $4.4 \mathrm{kgC} \mathrm{m}^{-2}$, $9.5 \mathrm{kgC} \mathrm{m}^{-2}$ and $9.8 \mathrm{kgC} \mathrm{m}^{-2}$ ). The average SOCS in Paris open soils was higher than SOCS in both forest and agricultural soils found in its region (5.6 and $4.8 \mathrm{kgC} \mathrm{m}^{-2}$, respectively). Concerning NYC 0-30 cm open soils, SOCS was at the same level of magnitude as SOCS found in the regional forest, for the same depth $\left(10.0 \mathrm{kgC} \mathrm{m}^{-2}\right)$, and it was much higher than agricultural soil SOCS $\left(4.0 \mathrm{kgC} \mathrm{m}^{-2}\right)$.
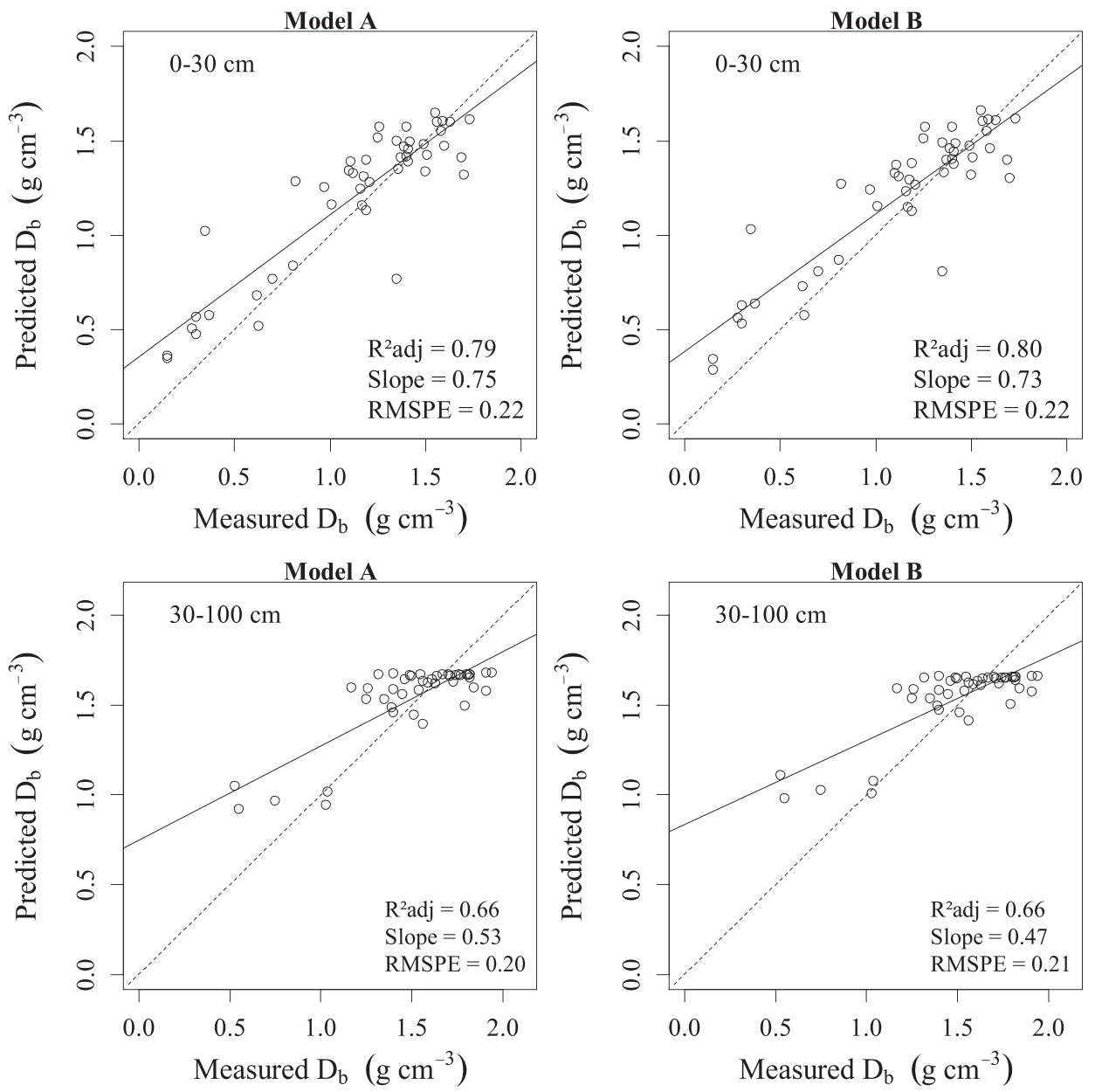

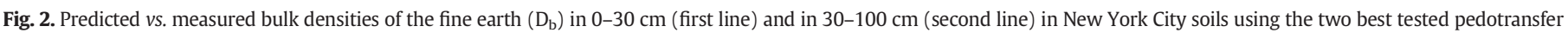
functions. 


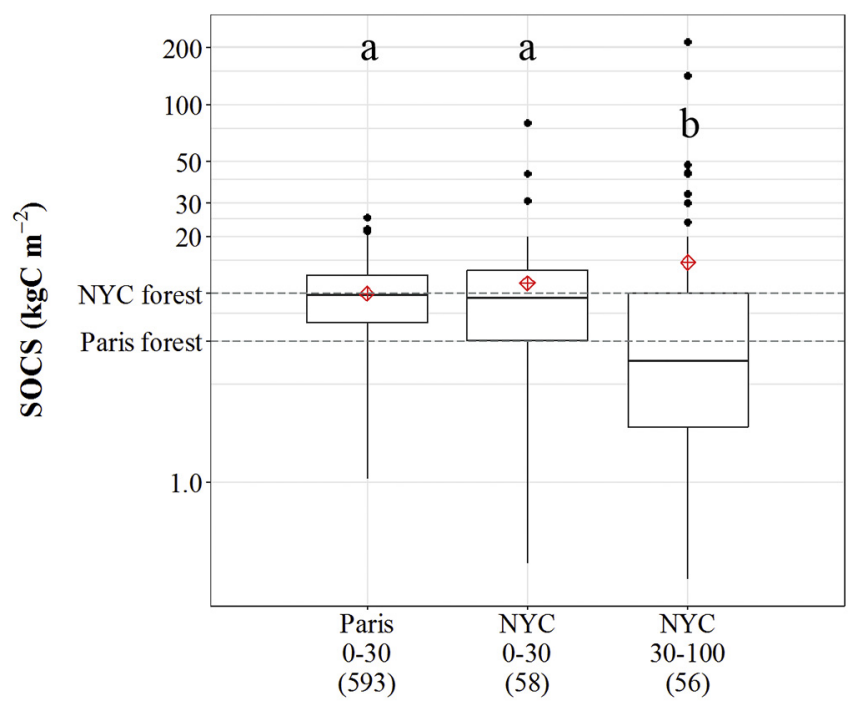

City and depth $* * *$

Fig. 3. Soil organic carbon stock (SOCS) distributions in open soils, in the three datasets: Paris 0-30 cm, NYC 0-30 cm and NYC 30-100 cm (logarithmic scale). The horizontal lines inside the boxes represent the median, the diamond-shaped symbols represent the mean. Bottom and top of the box are the first and third quartiles. The symbol “**** indicates that the multiple comparison (Kruskal-Wallis test followed by a Nemenyi posthoc test) provided $\mathrm{p}<0.001$ in open soils. The significant differences displayed by the statistical tests $(p=0.05$ ) are given by the letters: "a" is assigned to the dataset displaying the highest values. The numbers in brackets refer to the amount of data for each dataset. The average SOCS of forest soils were given for both Paris and NYC regions (long dash lines).

The variability of SOCS, mostly explained by SOC variability, was also very high in the soils of NYC compared to those from Paris. For all the open soils, the CV was respectively equal to $39 \%, 101 \%$ and $237 \%$ in Paris, NYC 0-30 cm and NYC 30-100 cm. These high values in NYC were, here again, mostly explained by the high CV of SOCS in fallows: it was $156 \%$ in NYC 0-30 cm and $208 \%$ and NYC $30-100 \mathrm{~cm}$.

\subsection{Factors influencing SOCS in open soils of both cities for the same depth}

In Paris, effects of the land use type and the geographic location (Paris city $v s$. its suburbs) on SOCS were studied. These factors displayed a significant effect on SOCS, even though the land use effect was less significant than the geographic location one $(0.001<\mathrm{p}<0.01$ for the land use; $\mathrm{p}<0.001$ for the geographic location; Fig. 4). Concerning the land use factor, the parks showed a significantly higher SOCS than the gardens and woodlands, with no significant difference between the two latter $\left(10.1 \pm 3.8 \mathrm{kgC} \mathrm{m}^{-2}, 8.1 \pm 4.9 \mathrm{kgC} \mathrm{m}^{-2}\right.$ and $7.3 \pm 4.0 \mathrm{kgC} \mathrm{m}^{-2}$ respectively). Moreover, Paris city displayed a significantly higher SOCS than its suburbs $\left(10.1 \pm 3.9 \mathrm{kgC} \mathrm{m}^{-2}\right.$ and $6.6 \pm 4.0 \mathrm{kgC} \mathrm{m}^{-2}$, respectively). These results allowed calculating SOCCT in the open soils of Paris. First, it was calculated for Paris city and its suburbs distinctly, as they displayed significantly different SOCS. Then, for each one of these locations, SOCCT was calculated: i) in the parks, using the average SOCS in parks and the corresponding surface area; ii) for all the other open spaces, using the average SOCS in woodlands and gardens multiplied by the remaining open soil surface area (i.e., excluding the parks; IAU Île-de-France Occupation du sol 2012). Finally, the SOCCT of all Paris open soils was obtained by adding these results.

In NYC 0-30 cm, only the parent material had a significant effect on SOCS $(0.001<\mathrm{p}<0.01$; Fig. 5). Technosols formed in coal ash displayed the highest SOCS, and despite its higher mean, it was not significantly different from the soils of tidal marshes (SOCS mean was $47.6 \pm$ $30.2 \mathrm{kgC} \mathrm{m}^{-2}$ and $14.2 \pm 3.9 \mathrm{kgC} \mathrm{m}^{-2}$, respectively). Both were significantly higher than SOCS of soils formed in dredgic fill (3.0 \pm $0.8 \mathrm{kgC} \mathrm{m}^{-2}$ ), which are very sandy (>90\% sand). As they were both included in the fallow land use, the high difference of SOCS (and SOC) between the coal ash and the dredgic fill could explain the very high CV of SOCS (and SOC) in the fallows. All the other types of parent material were not significantly different from these two groups (SOCS mean was comprised between $9.5 \mathrm{kgC} \mathrm{m}^{-2}$ and $11.7 \mathrm{kgC} \mathrm{m}^{-2}$ ). Concerning the land use effect in NYC $0-30 \mathrm{~cm}$, in contradiction with the results in Paris, this factor did not show a significant effect (Fig. 5). More specifically, SOCS in parks and woodlands were not significantly different in NYC ( $10.1 \pm 6.6 \mathrm{kgC} \mathrm{m}^{-2}$ and $10.4 \pm 3.7 \mathrm{kgC} \mathrm{m}^{-2}$, respectively). Finally, the parent material effect was studied in NYC $30-100 \mathrm{~cm}$ and displayed a very significant effect as well $(p<0.001)$. Thus, for the NYC open soils,

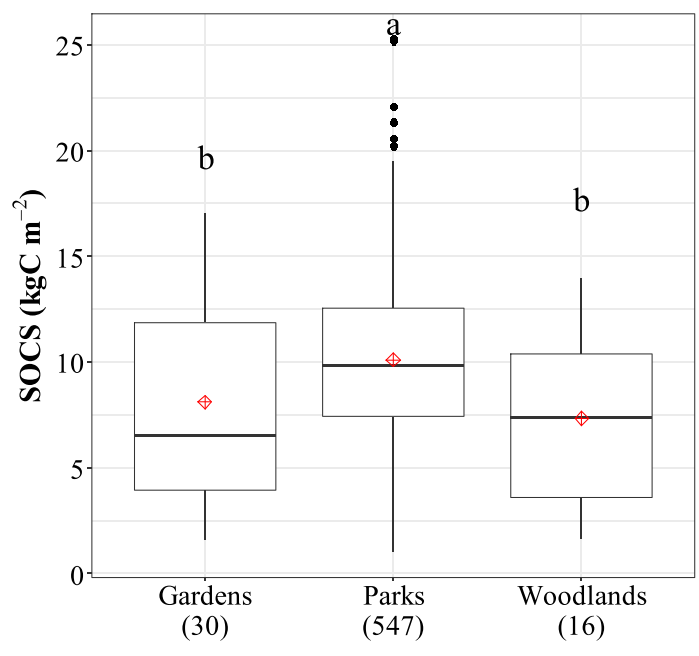

Land use (Paris) **

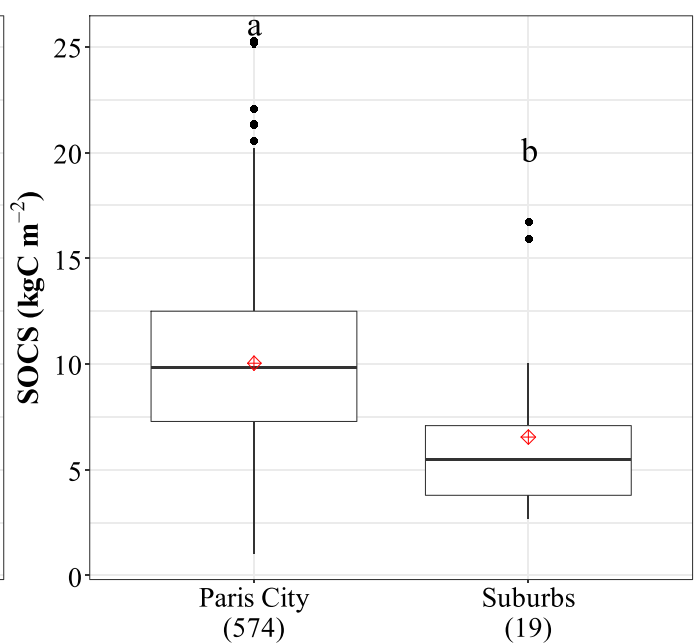

Location (Paris) ***

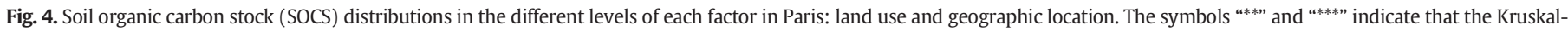

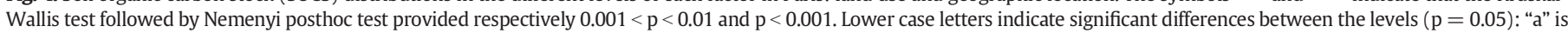
assigned to the dataset displaying the highest values. The numbers in brackets refer to the amount of data for each dataset. 

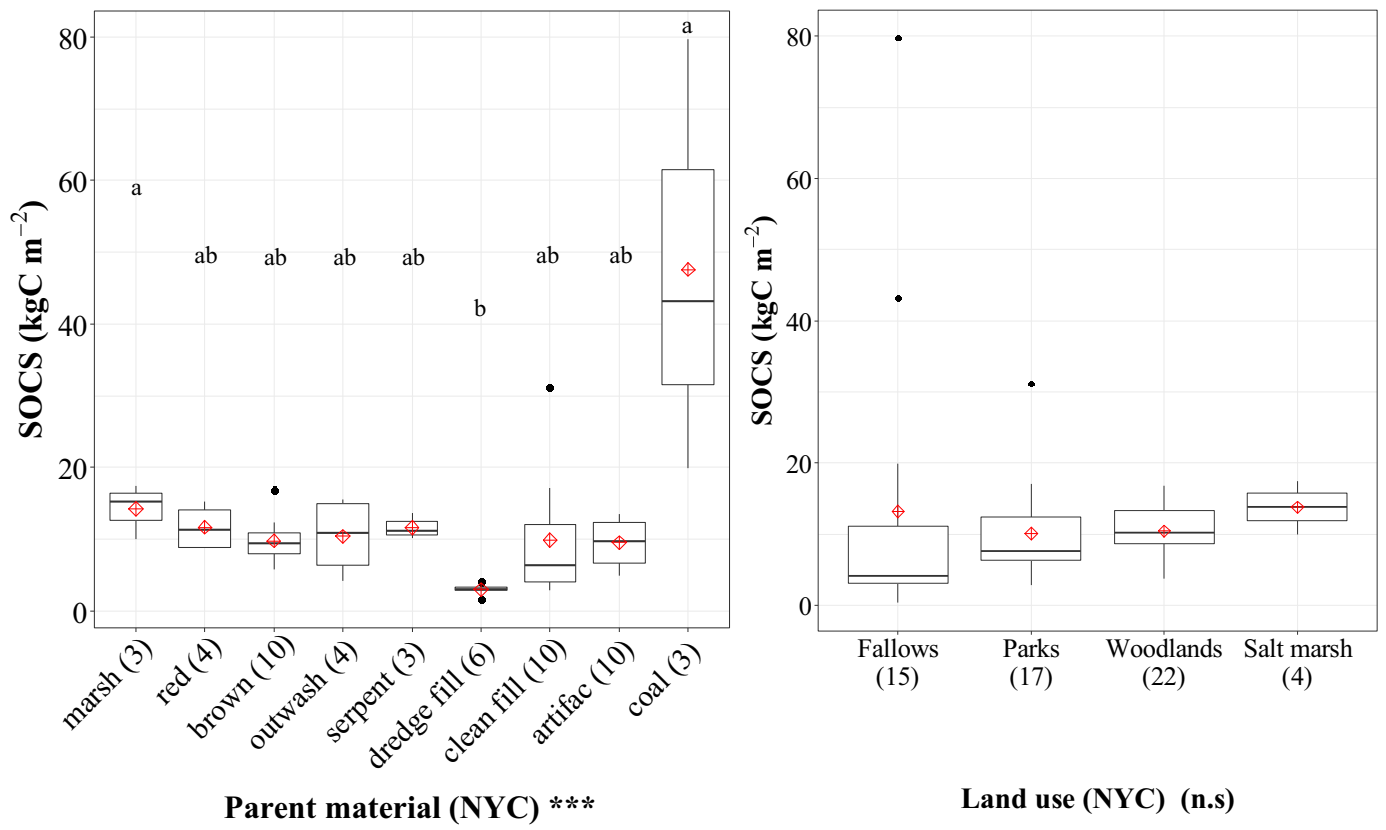

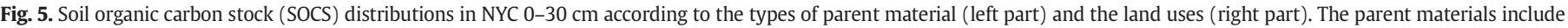

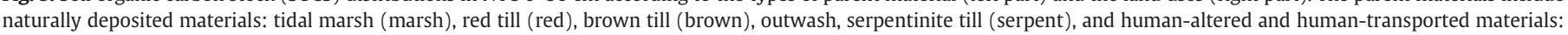

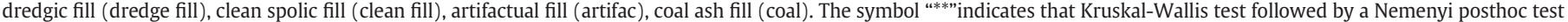

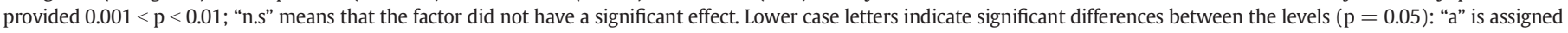

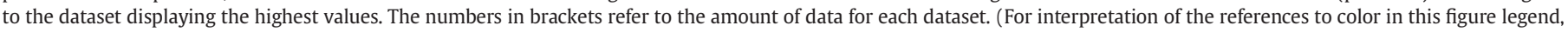
the reader is referred to the web version of this article.)

SOCCT was calculated according to their parent material: each one was subdivided into different mapped soil series, which were therefore used for this calculation, in order to be even more precise. Hence, SOCCT was calculated for each soil series from the SOCS value of the representative pedon or the average of the SOCS values estimated on several pedons multiplied by the land surface area occupied by the soil series across the city, based on the soil survey. For some soil series, the SOCS values were estimated from similar soil series or from data obtained on pedons of the same soil series sampled just outside the city. Finally, for each depth, the total SOCCT was calculated in NYC open soils by adding the results obtained for each soil series.

\subsection{Soil organic carbon citywide totals of open soils}

In the open soils, SOCCT was lower in Paris than in NYC 0-30 cm: it reached $1.6 \mathrm{TgC}$ in Paris and $2.4 \mathrm{TgC}$ in NYC $0-30 \mathrm{~cm}$ (Fig. 6). Nevertheless, the result obtained in Paris was higher than if its open soils were occupied by the regional forests or agricultural soils. Indeed, in Paris, for a surface area of $233 \mathrm{~km}^{2}$, SOCCT would be $1.3 \mathrm{TgC}$ for non-urban forests and it would be $1.1 \mathrm{TgC}$ for agricultural soils. Concerning NYC $0-30 \mathrm{~cm}$, SOCCT would be higher if the regional forest replaced the urban open soils: for a surface area of $289 \mathrm{~km}^{2}$, the soils would have a SOCCT of $2.9 \mathrm{TgC}$. However, as well as in Paris, SOCCT would be much

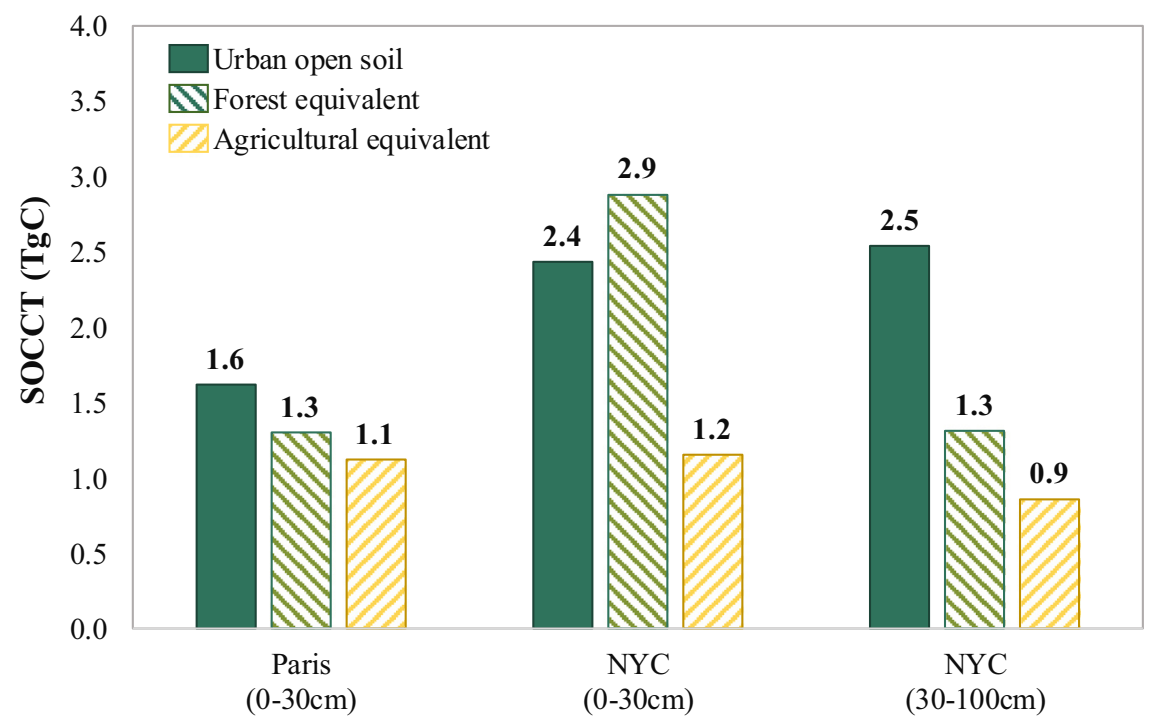

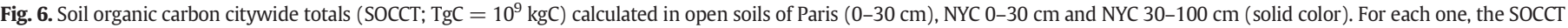

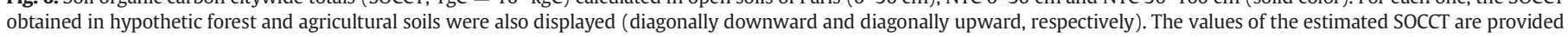
over the bars. 
lower in NYC open soils if they were occupied by the regional agricultural soils (1.2 $\mathrm{TgC})$.

In NYC 30-100 cm, SOCCT was $2.5 \mathrm{TgC}$ in open soils, which was equivalent to SOCCT in NYC 0-30 cm. Moreover, for the same depth, the urban open subsoils had a much higher SOCCT than if they were occupied by the regional non-urban forest or agricultural land use (1.3 $\mathrm{TgC}$ in forest and $0.9 \mathrm{TgC}$ in agricultural soils; Fig. 6).

\subsection{Soil organic carbon in sealed soils}

To estimate SOCS in Paris, the average $D_{b}$ of NYC sealed soils ( $1.6 \pm$ $0.1 \mathrm{~g} \mathrm{~cm}^{-3}$ ) was used as the estimated $D_{b}$ for sealed soils in Paris.

The values of SOCS in sealed soils were not significantly different between Paris ( $\left.3.4 \pm 1.2 \mathrm{kgC} \mathrm{m}^{-2}\right)$ and NYC ( $2.9 \pm 2.6 \mathrm{kgC} \mathrm{m}^{-2}$; Table 4); but they were both significantly lower than SOCS in open soils, in the $0-30 \mathrm{~cm}$ depth $\left(9.9 \pm 3.9 \mathrm{kgC} \mathrm{m}^{-2}\right.$ in Paris and $11.3 \pm 11.5 \mathrm{kgC} \mathrm{m}^{-2}$ in NYC). However, for the 30-100 cm depth in NYC, the SOCS values calculated in sealed soils were not significantly different from the ones found in open subsoils. Even if their SOCS mean values were very different, because of high values in the NYC $30-100 \mathrm{~cm}$ open soils, their median values were respectively $4.9 \mathrm{kgC} \mathrm{m}^{-2}$ and $4.4 \mathrm{kgC} \mathrm{m}^{-2}$. The SOCCT calculated in sealed soils (for $564 \mathrm{~km}^{2}$ in Paris and $489 \mathrm{~km}^{2}$ in NYC) were respectively $1.9 \mathrm{TgC}$ in Paris and $1.4 \mathrm{TgC}$ in NYC, for the first $30 \mathrm{~cm}$ of soils; it reached $3.2 \mathrm{TgC}$ in NYC $30-100 \mathrm{~cm}$ (Table 4). Thus, including both open and sealed soils, the citywide SOCCT values were similar in Paris and NYC 0-30 cm: SOCCT was 3.5 TgC in Paris and 3.8 TgC in NYC 0-30 cm. It was finally higher in NYC $30-100 \mathrm{~cm}$ with $5.8 \mathrm{TgC}$. If the total surface area $\left(798 \mathrm{~km}^{2}\right)$ in Paris was occupied by its regional forest and agricultural soils, the SOCCT would respectively reach $4.4 \mathrm{TgC}$ and $3.8 \mathrm{TgC}$, for the $0-30 \mathrm{~cm}$ depth. In NYC $\left(772 \mathrm{~km}^{2}\right)$, for $0-30 \mathrm{~cm}$ depth, it would respectively reach $7.7 \mathrm{TgC}$ and $3.1 \mathrm{TgC}$ for forests and agricultural soils. Finally, in $30-100 \mathrm{~cm}$ depth, SOCCT would reach $3.5 \mathrm{TgC}$ if NYC was occupied by its regional forests, and it would reach $2.3 \mathrm{TgC}$ if NYC was occupied by its regional agricultural soils.

\section{Discussion}

\subsection{Comparison of SOC and SOCS between NYC and Paris}

If compared globally, the open soils of Paris and NYC 0-30 cm displayed different SOC, lower in Paris than in NYC; however, this trend was observed in urban woodlands, but not in parks. Moreover, in this study, the non-urban forest soils near Paris contained less organic carbon than the ones near NYC. Pouyat et al. (2009) displayed that the management intensity in cities could remove the effect of natural factors (such as climate) on SOC and SOCS. In their study, for the $0-20 \mathrm{~cm}$ depth, SOCS was not significantly different between the turf grass soils of the Baltimore and Denver metropolitan areas $(11.0 \pm$ $0.9 \mathrm{kgC} \mathrm{m}^{-2}$ and $12.7 \pm 1.3 \mathrm{kgC} \mathrm{m}^{-2}$, respectively), whereas Baltimore rural soils had 60\% higher SOCS than Denver ones. This could explain why SOC was different between the Paris and NYC woodlands (and between their regional forests), which are less managed and disturbed

Table 4

Soil organic carbon stocks (SOCS; $\mathrm{kgC} \mathrm{m}^{-2}$ ) and citywide totals (SOCCT; $\mathrm{TgC}$ ) in the sealed soils of Paris, NYC $(0-30 \mathrm{~cm})$ and NYC $(30-100 \mathrm{~cm})$; SD is the standard deviation; $\mathrm{N}$ is the amount of data. The letters "n.s" mean that there was a non-significant difference of SOCS between Paris and NYC, for $0-30 \mathrm{~cm}$ depth $(\mathrm{p}=0.05)$.

\begin{tabular}{|c|c|c|c|c|c|c|c|c|c|}
\hline \multirow[t]{2}{*}{ Region } & \multirow[t]{2}{*}{ Category } & \multirow{2}{*}{$\begin{array}{l}\text { Depth } \\
\text { under } \\
\text { impervious } \\
\text { layer }(\mathrm{cm})\end{array}$} & \multirow[b]{2}{*}{$\mathrm{N}$} & \multicolumn{5}{|c|}{$\operatorname{SOCS}\left(\mathrm{kgC} \mathrm{m}^{-2}\right)$} & \multirow{2}{*}{$\begin{array}{l}\text { SOCCT } \\
(\operatorname{TgC})\end{array}$} \\
\hline & & & & Median & Mean & SD & Min & $\operatorname{Max}$ & \\
\hline Paris & Sidewalk & $0-30$ & 7 & $\begin{array}{l}3.2(\mathrm{n} . \\
\mathrm{s})\end{array}$ & 3.4 & 1.2 & 2.0 & 5.3 & 1.9 \\
\hline NYC & Road & $0-30$ & 8 & 2.1 & 2.9 & 2.6 & 0.2 & 7.8 & 1.4 \\
\hline NYC & Road & $30-100$ & 8 & 4.9 & 6.7 & 6.1 & 0.5 & 18.2 & 3.2 \\
\hline
\end{tabular}

soils, whereas SOC was not significantly different in the parks of these two cities. Indeed, management intensity is quite similar between both cities: the green spaces, particularly the lawns, are used to being highly managed: several mowings per year with, in many cases, exportation of the clipped grass (Paris Green Space and Environmental Division; New York City Department of Parks and Recreation, pers. comm.). They are also characterized by an old tradition of irrigation and fertilization inputs, which may have led, in both cities, to a high root and shoot biomass productivity in the park lawn, and a high organic carbon input into the soil (Falk, 1980).

Moreover, the history of park creation in NYC and Paris could explain their SOC homogeneity (the CV of SOC in parks were quite similar between Paris and NYC and it was the lowest in NYC compared to its other land uses). In NYC, most of the parks were built during the 19th century: local glacial till and outwash deposits were the source for much of the human-transported soil material used in parks. Since they were initially low in organic carbon, lime and fertilizer were added to provide a better plant growth medium: this, as well as the turf grass contribution to organic matter enrichment could have increased and homogenized SOC in these soils. In Paris, two main categories of substrates can be found in green spaces. The first one, originally rich in organic carbon, was also used at the 19th century, when the biggest parks of Paris city were created. The second category, initially poorer in organic carbon but still fertile, was used to create new smaller green spaces in Paris city and to expand its suburbs (Paris Green Space and Environmental Division, pers. comm.).

Thus, the history and management seem to have a strong effect on SOC in parks, which surpasses the influence of the natural factors, such as climate or the natural parent material. However, for all open soils together, climate and natural parent material could nevertheless explain the higher values and distribution of SOC in NYC than in Paris (i.e. in woodlands and fallows). Indeed, although the long history of the Parisian soils have led to high amount of backfill deposits in most places of the city, some areas may be less disturbed and still be influenced by the natural parent material. Yet, the natural parent materials in Paris are mainly sedimentary and calcareous, whereas NYC naturally deposited materials are very heterogeneous and can accumulate large amounts of organic carbon (e.g., in the many wetlands and salt marshes of the NYC islands). Moreover, SOC generally increases when the rainfall rate is higher, which is the case in NYC (1270 mm year ${ }^{-1}$ ) compared to Paris (591 mm year ${ }^{-1}$; Azlan et al., 2013; Burke et al., 1989; Selhorst and Lal, 2012).

Concerning SOCS, Paris and NYC open soils displayed equivalent SOCS for a same depth (respectively $9.9 \pm 3.9 \mathrm{kgC} \mathrm{m}^{-2}$ and $11.3 \pm$ $11.5 \mathrm{kgC} \mathrm{m}^{-2}$ ). This result observed for SOCS values, but not for SOC, was mostly due to the coarse fraction volumetric content, which was lower in Paris than in NYC (means were 5.9\% vs. 11.0\%, respectively) while $D_{\mathrm{b}}$ was not significantly different between both datasets. Globally, for the same depth, Hao et al. (2013) reported that SOCS of urban open soils in China (Tianjin Binhai New Area) reached $9.2 \mathrm{kgC} \mathrm{m}^{-2}$, which was at the same level of magnitude as SOCS in Paris and NYC.

In parks, SOCS means were very close between Paris and NYC, for the $0-30 \mathrm{~cm}$ depth: respectively $10.1 \pm 3.8 \mathrm{kgC} \mathrm{m}^{-2}$ and $10.1 \pm$ $6.6 \mathrm{kgC} \mathrm{m}^{-2}$, which could be explained by the similar park management and history between both cities, as well as for SOC. Lower values were found by Bae and Ryu (2015), in the Seoul Forest Park (SOCS mean was comprised between 1.0 and $8.0 \mathrm{kgC} \mathrm{m}^{-2}$ under vegetation), but this park was very young, only built in the 2000s on wastelands and bare soils, whereas many parks in Paris and NYC are over 100 years old.

In Paris, contrary to NYC, the land use displayed a significant effect on SOCS, in the $0-30 \mathrm{~cm}$ depth. A lack of representation of the woodland soils in the Paris dataset could contribute to the low value of SOCS in these soils. Nevertheless, as mentioned for SOC, the higher SOCS in managed parks than in less managed woodlands $\left(10.1 \pm 3.8 \mathrm{kgC} \mathrm{m}^{-2} v \mathrm{~s} .7 .3\right.$ $\pm 4.0 \mathrm{kgC} \mathrm{m}^{-2}$ ) could also be due to the old practice of irrigation and fertilization inputs in the Paris parks, leading to a higher contribution 
of lawns to increase SOCS. This hypothesis could be confirmed by the SOCS found in the regional forests, which was much lower than in the urban parks and close to the SOCS in urban woodlands $\left(5.6 \mathrm{kgC} \mathrm{m}^{-2}\right.$ in regional forests). This reasoning could also be applied to NYC: although the parks were established on areas originally very poor in organic carbon, no significant difference of SOCS was found with the other NYC land uses, i.e., woodlands, fallows, salt marshes, at the time of this study. Concerning the garden category in Paris, their lower SOCS compared to that of parks could be explained by the fact that half of the garden samples were collected in the suburbs. Yet, the suburbs displayed globally a significantly lower SOCS than Paris city, probably due to historical origin. As mentioned before, a part of Paris city green spaces (mostly the largest parks) were created during the Haussmann period, using the market garden soils, rich in organic matter; whereas, with the expansion of its suburbs, arable soils were used to create the suburbs' green spaces (poorer in organic carbon). However, there was also a notable difference in the amount of data between Paris city and its suburbs, leading to a lack of representation of the suburbs compared to Paris city.

In NYC, only the parent material displayed an effect: this study showed that the human-altered and human-transported materials could be the source of higher SOCS (i.e., coal ash), which was in accordance with the results displayed by Trammell et al. (2011). This work also showed that, as in Yan et al. (2015), the anthropic activities can induce high SOCS at depth. Indeed, those soils very disturbed by human activities (i.e., parks and fallows) did not display a significant vertical trend of SOCS; whereas in urban woodlands, which are globally less impacted by the human disturbance, SOCS decreased with depth. Thus, SOCS in urban open subsoils is significant as it can reach very high values (e.g., the maximum SOCS value reached $216.3 \mathrm{kgC} \mathrm{m}^{-2}$ in NYC between 30 and $100 \mathrm{~cm}$ of depth).

This first part showed that human activities can increase SOCS by introducing some OC-rich anthropogenic materials (e.g., coal ash) or through their open soil management. Moreover, the similar SOCS values and variability observed in the parks of these two cities could suggest that the management methods, if adapted to the climate and parent material, might lead to a homogenization of SOCS in the parks of different cities (Pouyat et al., 2009). However, it was not possible to estimate, with the available data, the carbon budget associated with these management methods, nor the carbon sustainability in urban soils. Yet, some hypothesis could be proposed for the latter: for example, the coal ash found in NYC represents recalcitrant black carbon, which is stored long-term; the same is true for SOCS in subsoils, characterized by a high organic carbon mean residence time (Rumpel et al., 2012). On the contrary, according to Vasenev and Kuzyakov (2017), management activities of green spaces such as fertilization, irrigation and lawn mowing (or tree/shrub pruning), which are first associated with high energy consumption, could also contribute to intensive microbial activity, responsible for outgoing fluxes from the open topsoils.

In contradiction with the ability of human activities to increase SOCS, it can also decrease SOCS at a given point in time and space, for example, by sealing soils. Indeed, in NYC and in Paris, SOCS in sealed soils were much lower than in open soils. This observation can be first explained by the topsoil and its organic carbon removal, which systematically occurs when a soil is sealed; secondly, soil sealing prevents the fluxes between soils with the other pools, so that they cannot accumulate organic carbon anymore. The data did not allow assessing the fate of the removed topsoil but even if these topsoils are often reused as substrates for new parks within the city, the disturbance might affect their SOCS, at least in the short term. The SOCS in sealed soils could only be measured on a few samples in NYC, but the values obtained were comprised within the range found in the literature. Indeed, in the literature, for the first $20 \mathrm{~cm}$ of depth, SOCS was comprised between $1.7 \mathrm{kgC} \mathrm{m}^{-2}$ (Yan et al., 2015) and $3.2 \mathrm{kgC} \mathrm{m}^{-2}$ (under sidewalks, with the hypothesis of SOCS homogenously distributed in the soil profile; Edmondson et al., 2012). This interval also included SOCS equal to $2.2 \mathrm{kgC} \mathrm{m}^{-2}$ under roads in Edmondson et al. (2012) and $2.5 \mathrm{kgC} \mathrm{m}^{-2}$ in Wei et al. (2014a). Here, NYC SOCS would be equal to $1.9 \mathrm{kgC} \mathrm{m}^{-2}$ for $0-20 \mathrm{~cm}$ of depth.

In our study, the results between sealed soils and open soils followed the ones displayed in Raciti et al. (2012), Yan et al. (2015) and Wei et al. (2014a): they respectively found that SOCS in sealed soils were $66 \%$, $75 \%$ and $68 \%$ lower than in open soils (in $0-15 \mathrm{~cm}, 0-20 \mathrm{~cm}$ and 0-20 cm of depth, respectively). Here, SOCS in sealed soils were respectively 66\% and 77\% lower than in open soils, in Paris and NYC 0-30 cm. Therefore, this study approved the conclusion of Yan et al. (2015): the sealed soils SOCS should not be approximated with the adjacent open topsoil SOCS. However, we displayed that SOCS in 30-100 cm of depth of sealed soils and open soils were not significantly different in NYC, which is understandable because, as mentioned before, the sealed soils often correspond to subsoils, after the topsoil removal.

\subsection{Contribution of these two cities to the soil organic carbon totals}

In this study, the global carbon stocks in both cities were assessed by the calculation of SOCCT, taking into account the open soils and the sealed soils at one given point in time. In the open soils, SOCCT values were slightly higher in NYC than in Paris. This difference was mainly due to the difference of open surface areas between both cities: $289 \mathrm{~km}^{2}$ in NYC and $233 \mathrm{~km}^{2}$ in Paris. The comparison of SOCCT with forest and agricultural soils for the same areas and for 0-30 cm depth, demonstrated a high contribution of the urban open topsoils to the global stocks. Indeed, SOCCT in Paris was higher than its forest ones $(+24.5 \%)$; it was a bit lower in NYC $(-15.7 \%$ in NYC than its regional forest soils). Moreover, it was much higher than the agricultural ones $(+44.5 \%$ in Paris than agricultural soils; $+110.4 \%$ in NYC than its regional agricultural soils). The lower SOCCT observed in NYC open soils compared to its regional forest belies the results obtained for SOCS, similar between both; this is due to the weighted calculation of SOCCT using surface areas, reducing the influence of the extremely high SOCS values in the result.

This study also displayed the high contribution of urban open subsoils, which was much higher than the forest or agricultural subsoil ones for the same depth: $+93.8 \%$ (i.e. 1.9 times greater) in NYC $30-100 \mathrm{~cm}$ than in forest $30-100 \mathrm{~cm} ;+195.2 \%$ (i.e. 3.0 times more) in NYC $30-100 \mathrm{~cm}$ than in agricultural soils $30-100 \mathrm{~cm}$. At the profile level $(0-100 \mathrm{~cm})$, the contribution of NYC urban open soils was, hence, higher than the forest and agricultural soils $(+18.5 \%$ and $+146.6 \%$, respectively).

When the sealed soils were taken into account, the SOCCT values were at the same level of magnitude in both cities, even if it was a bit lower in Paris than in NYC (3.5 TgC and 3.8 TgC in Paris and NYC, respectively). This very small difference, whereas the total Paris surface area was slightly higher than that of NYC, was, here again, mainly due to the difference of proportions between sealed soils and open soils in both cities: $62 \%$ of sealed soils vs. $38 \%$ of open soils in NYC and $70 \% v$ s. $30 \%$ in Paris. Thus, the potential of urban soils to contribute to the global stock is strongly depending on this percentage of sealed soils. Thus, by including the sealed soils, topsoil SOCCT became lower in cities than in the regional forests $(-20.5 \%$ in Paris and $-50.6 \%$ in NYC) and at the same level of magnitude as in the regional agricultural soils $(-7.9 \%$ in Paris and $+22.6 \%$ in NYC). Thus, it is obvious that the citywide topsoil contribution would increase by limiting soil sealing, and it could even become higher or close to the forest soil value, at a given point in time.

In the 30-100 cm depth, no significant difference of SOCS was observed between open soils and sealed soils in NYC, so, as the sealed soil area was higher than the open soils', SOCCT was also higher in sealed soils than in open soils, at this depth (3.2 TgC vs. 2.5 TgC). Moreover, SOCCT in NYC open and sealed subsoils was much higher than in forest or agricultural subsoils calculated for NYC surface area $\left(772 \mathrm{~km}^{2}\right)$ : SOCCT was 1.7 times higher in NYC subsoils than in forest 
subsoils and 2.5 times higher than in agricultural subsoils. Thus, in urban soils, the hidden, deeper stocks are very important for soil organic carbon assessment since they also display a significant contribution to the global stock.

For $0-100 \mathrm{~cm}$ of depth in NYC including the sealed soils, SOCCT reached $9.6 \mathrm{TgC}$, which was much higher than the results obtained by Pouyat et al. (2006) in other cities of USA: they found SOCCT comprised between $0.8 \mathrm{TgC}$ in Oakland $\left(132 \mathrm{~km}^{2}\right)$ and $3.4 \mathrm{TgC}$ in Chicago $\left(614 \mathrm{~km}^{2}\right)$. These low values compared to ours could not be only due to the difference of total areas. First, their estimation of SOCS in the sealed soils was much lower than our results $\left(3.3 \mathrm{kgC} \mathrm{m}^{-2} v s\right.$. $9.6 \mathrm{kgC} \mathrm{m}{ }^{-2}$ for $0-100 \mathrm{~cm}$ of depth, respectively). Then, there was also a high difference of SOCS in open soils between both studies: for example, in our study, the parks in NYC $(0-100 \mathrm{~cm})$ displayed a SOCS mean equal to $35.4 \mathrm{kgC} \mathrm{m}^{-2}$, whereas it was only $7.4 \mathrm{kgC} \mathrm{m}^{-2}$ in Atlanta, in Pouyat et al. (2006). That difference could be due to the climate effect, as Atlanta is characterized by higher temperatures than in NYC (mean air temperature of $16.4{ }^{\circ} \mathrm{C}$ in Atlanta; Azlan et al., 2013; Burke et al., 1989). However, in Edmondson et al. (2012), SOCCT in Leicester reached $0.98 \mathrm{TgC}$ for $0-100 \mathrm{~cm}$ of soil and for $73 \mathrm{~km}^{2}$; thus, if calculated for the same area as NYC one, SOCCT would reach $10.4 \mathrm{TgC}$, which is very similar to the SOCCT in NYC $(0-100 \mathrm{~cm})$. Compared to the New Jersey forest and agricultural soils, the citywide SOCCT calculated at $0-100 \mathrm{~cm}$ depth (including sealed soils) would be slightly lower than SOCCT in forest $(-14.3 \%)$ but it would be higher than in agricultural soils ( $+77.8 \%$ or 1.8 times more).

However, the results are also strongly dependent on the method used to calculate SOCCT. Indeed, without distinguishing the significantly different SOCS values between the factor levels, which had an effect on SOCS values, the open soils' SOCCT would have been overestimated in both cities. In Paris open soils, without distinguishing SOCS of Paris city from in its suburbs, nor distinguishing SOCS in parks from in the other land uses, SOCCT would reach $2.3 \mathrm{TgC}$ (instead of $1.6 \mathrm{TgC}$, by using the average SOCS obtained for all the open soils together, i.e. $9.9 \mathrm{kgC} \mathrm{m}^{-2}$ ). In NYC $0-30 \mathrm{~cm}$, without performing the distinction between the different soil series, SOCCT would reach $3.7 \mathrm{TgC}$ (instead of $2.4 \mathrm{TgC}$, by using the average SOCS obtained for all the open soils, i.e. $12.7 \mathrm{kgC} \mathrm{m}^{-2}$ ). Thus, a preliminary factor effect study is necessary to be the closest possible to the real values of SOCCT.

\subsection{Limits of the methodology}

In the literature, many methods have been used to calculate SOCS in urban soils, which can potentially lead to a strong bias for the accurate estimation of SOCS in cities. To be able to use the formula proposed by Poeplau et al. (2017), several parameters must be accurately determined: SOC, $D_{b}, \delta_{2 m m} v / v$ and $H$.

\subsubsection{Estimation of the bulk density}

In this study, the methodology used was not standardized and had some limitations, in particular, to process the Paris data. Indeed, the sampling methodology was not standardized there, thus some estimations had to be performed, particularly for $\mathrm{D}_{\mathrm{b}}$. Beforehand, PTFs using other parameters than SOC (i.e. clay, silt; Bernoux et al., 1998; Tomasella and Hodnett, 1998) were also tested but the results were not good, so that only SOC was used in this study. Considering the topsoils $(0-30 \mathrm{~cm})$, the $D_{b}$ estimation gave satisfactory results for urban soils compared to the ones found in the literature for non-urban soils. However, the RMSPE was higher than in some results found in the literature (Kaur et al., 2002). This could be explained by the high heterogeneity of SOC in NYC datasets, compared to the literature one (SD of SOC in the training and validation subsets were $121.6 \mathrm{gC} \mathrm{kg}^{-1}$ and 95.6 $\mathrm{gC} \mathrm{kg}^{-1}$ in this study, whereas they were $3.8 \mathrm{gC} \mathrm{kg}^{-1}$ and $4.3 \mathrm{gC} \mathrm{kg}^{-1}$ in Kaur et al., 2002). Hence, the accuracy of the models performed in this study was not optimum: the error of $D_{b}$ estimation was not negligible and the slope was far from one. This was particularly the case for
30-100 cm depth, for which the models were not efficient. Moreover, it was not possible to validate this model on some Paris $D_{b}$ values (as this parameter had never been studied in Paris database); thus, according to Kaur et al. (2002), the estimated $D_{b}$ have to be used with care, even if Paris SOC were comprised within the range of SOC in NYC $0-30 \mathrm{~cm}$.

Thus, to go further in SOCS assessment, it would have been necessary to determine accurately the bulk density of the fine earth for each sample.

\subsubsection{Estimation of the coarse fraction volumetric content}

The coarse fraction estimation in the soils of NYC and Paris was limited too; this parameter should be more precisely studied in the future soil organic carbon assessment work. Indeed, its estimation was based on the assumption that the particle gravity of rock fragments was $2.7 \mathrm{~g} \mathrm{~cm}^{-3}$ and $D_{b}$ of the fine earth fraction was $1.5 \mathrm{~g} \mathrm{~cm}^{-3}$. Yet, as seen in this study, the average $D_{b}$, really measured in the fine earth, was $1.2 \pm 0.3 \mathrm{~g} \mathrm{~cm}^{-3}$ in NYC $0-30 \mathrm{~cm}$; it was $1.4 \pm 0.4 \mathrm{~g} \mathrm{~cm}^{-3}$ in NYC $30-100 \mathrm{~cm}$, and it was $1.6 \pm 0.1 \mathrm{~g} \mathrm{~cm}^{-3}$ in NYC sealed soils. Moreover, the coarse fraction could have contained macroorganism residues (vegetal or animal) or black carbon, whose density values are generally much lower than $2.7 \mathrm{~g} \mathrm{~cm}^{-3}$. Then, in urban soils, the possibility to assume that the coarse fraction does not contain organic carbon is more hazardous, since in cities, different types of artifacts are often provided to the soils by human activities and they can contain organic carbon (e.g., charcoal). Thus, it would be necessary, in urban soils, to calculate the SOCS contained in the coarse fraction too.

\subsubsection{Studied depth}

Another parameter important to consider with SOCS is the depth to be examined. First, this study showed that the studied depth should not be limited to $0-30 \mathrm{~cm}$ : indeed, in NYC, the SOCCT was equal to $3.8 \mathrm{TgC}$ in the first $30 \mathrm{~cm}$; however, it reached $9.6 \mathrm{TgC}$ for $0-100 \mathrm{~cm}$ of depth, which is 2.5 times the value in $0-30 \mathrm{~cm}$. Moreover, as said before, in urban subsoils, the values of SOCS can be very high, which must not be disregarded to understand the potential of cities to stock organic carbon. Then, the determination of the soil parameters must be more accurate if performed by pedological horizon, as it was done in NYC, to take into account the real soil vertical variability, which can be very heterogeneous in urban soils.

\subsubsection{Sampling design}

Then, the sampling methodology can affect the results. First, the amount of data is an important question for soil organic carbon assessment: enough samples are needed to be representative of the spatial heterogeneity of SOCS in urban soils. In this study, a bias could have been introduced because of the comparison of SOCS between unbalanced datasets. Moreover, only seven and eight samples were collected in sealed soils in Paris and NYC, respectively. These numbers are low considering their surfaces areas and greater sampling campaigns should be launched to study SOCS in sealed soils. However, these soils are hardly accessible, so that their sampling have to be opportunistic; thus, most of the studies about sealed soils generally have to deal with few data (Wei et al., 2014a, 2014b; Yan et al., 2015). Then, the sampling design in sealed soils should have included distinctly sidewalks, roadways or even built-up soils in each city, as they can display different SOCS (Edmondson et al., 2012). Here again, the sampling design of sealed soils is limited by the opportunities for sampling (e.g., building reconstruction/demolition, works under roads or sidewalks).

Moreover, the sampling design in NYC, to include all important soil survey types, likely provided a strong heterogeneity of the results of SOC and SOCS, which was noticeable with the high CV of these parameters in this city. We can suppose that the choice of the sampling design in NYC, based on the parent material cartography, implied that only this factor displayed an effect on SOCS in NYC 0-30 cm. Indeed, if several repetitions of sampling were performed for a same series of soil, but 
with different land uses or vegetation covers, the results might have shown some effects of these factors. To be the most complete possible, the sampling points should be chosen by taking into account more potential sources of variability: for example, using also the cartography of land uses or types of cover. Then, only the sampling sites larger than $2000 \mathrm{~m}^{2}$ were retained for this study, but the smaller open soils should also be studied as they could display different SOCS. Indeed, their management, their cover or their establishment method could be different, mainly for the very small open surface areas, such as street trees or horticultural massifs.

\subsubsection{Lack of some dynamics data}

The results of this study were obtained at a given point in time; however, as shown in the study of Bae and Ryu (2015), which displayed that the land use and land cover changes could strongly impact the soil properties, including SOC, over a short period of time. These land use and land cover changes often occur in the urban environment, as cities are in constant evolution, and as the human activities/disturbance in cities are very heterogeneous. These activities often lead to different material inputs into the soils, among which, various types of organic carbon can potentially be found (e.g., presence of black carbon, more recalcitrant), which should be studied. Moreover, after its establishment, an urban land use/cover is probably the source of high amounts of $\mathrm{CO}_{2}$, through microbial respiration, because of the high management intensity. The management methods are themselves probably the source of high emissions of carbon, and may lead to a negative carbon budget. Thus, this study showed that the SOCS and SOCCT of urban soils could be higher or equivalent to the forest ones, but the outputs of carbon as $\mathrm{CO}_{2}$, which were not studied here were certainly higher than in forest as well. Thus, it would be necessary to quantify the citywide soil carbon fluxes to assess the effective urban soil contribution to carbon sequestration and more largely to climate change mitigation.

\section{Conclusion}

At this stage, the compilation of numerous existing data has allowed us to highlight, at the scale of NYC and Paris, some similar carbon stock trends. The SOCS in parks and in sealed soils were not significantly different between both cities. Moreover, SOCS in open urban topsoils were systematically higher than in agricultural soils. The SOCCT in NYC and Paris were very close when comparing open urban soils and sealed urban soils. In topsoils, SOCCT in areas with open soils could be greater than SOCCT in forests (in Paris) and agricultural soils (both cities). However, at the city scale, the high proportion of sealed soils in both cities strongly decreased the topsoil SOCCT. In subsoils, the contribution of urban soils to the global soil organic carbon totals was much higher than the forest or agricultural ones, even including the sealed soils, which shows the importance of hidden carbon in cities.

At the outcome of this work and from a methodological point of view, we suggest an enhanced standardization of the SOCS assessment in urban soils. The sampling design should be decided using all the potential sources of variability of urban soils. The open soils and sealed soils should be both studied, since SOCS in sealed soils is significant. As the deeper layers of urban soils can also store organic carbon, it is necessary to study SOCS along the whole urban soil profile and the calculation of SOCS should be performed for each pedological horizon, before summing the results over the studied depth. All the parameters involved in the equation to calculate SOCS should be determined and particularly soil bulk density, and the calculation of SOCS should include the coarse fraction. Finally, with the aim of increasing the storage of carbon in urban soils, it should be necessary to unseal soils or to maximise the proportion of open soils in the frame of development projects.

\section{Acknowledgements}

This study was supported by the SUPRA project (grant number 1772C0021), financed by ADEME (French Environmental Agency), which has also financed the PhD grant of the lead author, with the Région Pays de la Loire. The New York City Urban Soils Institute helped bring the authors together to discuss carbon in urban soils. We would like to thank the laboratory of agronomy of Paris and the laboratory of USDA and all associated technicians for providing the technical assistance in soil physicochemical analyses. We also would like to thank the INSEE (France), Infoclimat (France) and the IAU-IDF (Île-deFrance) for providing data. In the same idea, we thank the National Institute for Agronomic Research, INRA InfoSol (Orléans, France), for having provided RMQS data. Finally, we thank Olga Vargas (USDA-NRCS), for her help on GIS. This work is also the result of collaboration between members of the International Union of Soil Sciences (IUSS) SUITMA Working Group.

\section{References}

AFNOR, 1995. NF ISO 10694 - Qualité du sol-Dosage du carbone organique et du carbone total après combustion sèche (analyse élémentaire)

AFNOR, 1999. NF ISO 10693 - Qualité du sol-Détermination de la teneur en carbonateMéthode volumétrique.

Arrouays, D., Jolivet, C., Boulonne, L., Bodineau, G., Saby, N., Grolleau, E., 2002. A new projection in France: a multi-institutional soil quality monitoring network. Comptes Rendus Académie Agric. Fr. Fr.

Azlan, A., Weng, A., Ibrahim, C.O., Noorhaidah, A., 2013. Correlation between Soil Organic Matter, Total Organic Matter and Water Content with Climate and Depths of Soil at Different Land use in Kelantan, Malaysia.

Bae, J., Ryu, Y., 2015. Land use and land cover changes explain spatial and temporal variations of the soil organic carbon stocks in a constructed urban park. Landsc. Urban Plan. 136:57-67. https://doi.org/10.1016/j.landurbplan.2014.11.015.

Béchet, B., Carré, F., Florentin, L., Leyval, C., Montanarella, L., Morel, J., Raimbault, G., Rodriguez, F., Rossignol, J., Schwartz, C., 2009. Caractéristiques et fonctionnement des sols urbains. Cheverry Gascuel Éd Sous Pavés Terre Omniscience Montreuil, pp. $45-74$.

Bernoux, M., Cerri, C., Arrouays, D., Jolivet, C., Volkoff, B., 1998. Bulk densities of Brazilian Amazon soils related to other soil properties. Soil Sci. Soc. Am. J. 62, 743-749.

Burke, I.C., Yonker, C.M., Parton, W.J., Cole, C.V., Schimel, D.S., Flach, K., 1989. Texture, climate, and cultivation effects on soil organic matter content in U.S. grassland soils. Soil Sci. Soc. Am. J. 53:800. https://doi.org/10.2136/sssaj1989.03615995005300030029x.

Chen, S., Richer-de-Forges, A.C., Saby, N.P., Martin, M.P., Walter, C., Arrouays, D., 2018. Building a pedotransfer function for soil bulk density on regional dataset and testing its validity over a larger area. Geoderma 312:52-63. https://doi.org/10.1016/j. geoderma.2017.10.009.

Dignac, M.-F., Derrien, D., Barré, P., Barot, S., Cécillon, L., Chenu, C., Chevallier, T., Freschet, G.T., Garnier, P., Guenet, B., 2017. Increasing soil carbon storage: mechanisms, effects of agricultural practices and proxies. A review. Agron. Sustain. Dev. 37 (14). https:// doi.org/10.1007/s13593-017-0421-2.

Edmondson, J.L., Davies, Z.G., Mchugh, N., Gaston, K.J., Leake, J.R., 2012. Organic carbon hidden in urban ecosystems. Sci. Rep. 2. https://doi.org/10.1038/srep00963.

Elzhov, T.V., Mullen, K.M., Spiess, A.-N., Bolker, B., 2013. Minpack. Im: R interface to the Levenberg-Marquardt nonlinear least-squares algorithm found in MINPACK, plus support for bounds. R Package Version 1.1-8.

Falk, J.H., 1980. The primary productivity of lawns in a temperate environment. J. Appl. Ecol. 689-695.

Hao, C., Smith, J., Zhang, J., Meng, W., Li, H., 2013. Simulation of soil carbon changes due to land use change in urban areas in China. Front. Environ. Sci. Eng. 7:255-266. https:// doi.org/10.1007/s11783-013-0485-4

Huot, H., Joyner, J., Córdoba, A., Shaw, R.K., Wilson, M.A., Walker, R., Muth, T.R., Cheng, Z., 2017. Characterizing urban soils in New York City: profile properties and bacterial communities. J. Soils Sediments 17:393-407. https://doi.org/10.1007/s11368-016-1552-9.

Climate change 2014: synthesis report. In: IPCC, Core Writing Team, Pachauri, R.K., Meyer, L.A. (Eds.), Contribution of Working Groups I, II and III to the Fifth Assessment Report of the Intergovernmental Panel on Climate Change. IPCC. ed., Geneva, Switzerland.

ISO, 1998. NF ISO 14235 - Qualité du sol-Dosage du carbone organique par oxydation sulfochromique.

Jacobson, M., Charlson, R.J., Rodhe, H., Orians, G.H., 2000. Earth System Science: From Biogeochemical Cycles to Global Changes. Academic Press.

Kaur, R., Kumar, S., Gurung, H.P., 2002. A pedo-transfer function (PTF) for estimating soil bulk density from basic soil data and its comparison with existing PTFs. Soil Res. 40: 847-858. https://doi.org/10.1071/sr01023.

Minasny, B., Malone, B.P., Mcbratney, A.B., Angers, D.A., Arrouays, D., Chambers, A., Chaplot, V., Chen, Z.-S., Cheng, K., Das, B.S., Field, D.J., Gimona, A., Hedley, C.B., Hong, S.Y., Mandal, B., Marchant, B.P., Martin, M., McConkey, B.G., Mulder, V.L., O'Rourke, S., Richer-de-Forges, A.C., Odeh, I., Padarian, J., Paustian, K., Pan, G., Poggio, L., Savin, I., Stolbovoy, V., Stockmann, U., Sulaeman, Y., Tsui, C.-C., Vågen, T.G., van Wesemael, B., Winowiecki, L., 2017. Soil carbon 4 per mille. Geoderma 292: 59-86. https://doi.org/10.1016/j.geoderma.2017.01.002. 
Morel, J.L., Charzyński, P., Shaw, R.K., Zhang, G., 2015. The seventh SUITMA conference held in Toruń, Poland, September 2013. J. Soils Sediments 15, 1657-1658.

New York City Department of Parks \& Recreation (official website), d. https://www. nycgovparks.org/ (accessed on 2018.01.01).

New York City Soil Survey Staff, 2005. New York City Reconnaissance Soil Survey. United States Department of Agriculture. Natural Resources Conservation Service, Staten Island, NY.

Paustian, K., Lehmann, J., Ogle, S., Reay, D., Robertson, G.P., Smith, P., 2016. Climate-smart soils. Nature 532, 49-57.

Poeplau, C., Vos, C., Axel, D., 2017. Soil organic carbon stocks are systematically overestimated by misuse of the parameters bulk density and rock fragment content. Soil 3, 61 .

Pohlert, T., 2014. The pairwise multiple comparison of mean ranks package (PMCMR). R Package 2004-2006.

Pouyat, R.V., Yesilonis, I.D., Nowak, D.J., 2006. Carbon storage by urban soils in the United States. J. Environ. Qual. 35:1566. https://doi.org/10.2134/jeq2005.0215.

Pouyat, R.V., Yesilonis, I.D., Golubiewski, N.E., 2009. A comparison of soil organic carbon stocks between residential turf grass and native soil. Urban Ecosyst. 12:45-62. https://doi.org/10.1007/s11252-008-0059-6.

R Core Team, 2013. R: A Language and Environment for Statistical Computing.

Raciti, S.M., Hutyra, L.R., Finzi, A.C., 2012. Depleted soil carbon and nitrogen pools beneath impervious surfaces. Environ. Pollut. 164:248-251. https://doi.org/10.1016/j. envpol.2012.01.046.

Rumpel, C., Chabbi, A., Marschner, B., 2012. Carbon storage and sequestration in subsoil horizons: Knowledge, gaps and potentials. Recarbonization of the Biosphere. Springer, pp. 445-464.

Scharlemann, J.P., Tanner, E.V., Hiederer, R., Kapos, V., 2014. Global soil carbon: understanding and managing the largest terrestrial carbon pool. Carbon Manage. 5, 81-91.

Schoeneberger, P.J., Wysocky, D.A., Benham, E.C., Soil Survey Staff, 2012. Field book for describing and sampling soils, version 3.0. Natural Resources Conservation Service. National Soil Survey Center, Lincoln, NE.

Selhorst, A., Lal, R., 2012. Effects of climate and soil properties on US home lawn soil organic carbon concentration and pool. Environ. Manag. 50:1177-1192. https://doi. org/10.1007/s00267-012-9956-9.
Service de la Statistique et de la Prospective, 2015. Utilisation du territoire L'artificialisation des terres de 2006 à 2014: pour deux tiers sur des espaces agricoles. Agreste Primeur no. 326.

Seto, K.C., Güneralp, B., Hutyra, L.R., 2012. Global forecasts of urban expansion to 2030 and direct impacts on biodiversity and carbon pools. Proc. Natl. Acad. Sci. 109, 16083-16088.

Kellogg soil survey laboratory methods manual. In: Soil Survey Staff, Burt and Soil Survey Staff (Eds.), Soil Survey Investigations Report No. 42, Version 5.0. R. U.S. Department of Agriculture, Natural Resources Conservation Service.

Tomasella, J., Hodnett, M.G., 1998. Estimating soil water retention characteristics from limited data in Brazilian Amazonia. Soil Sci. 163:190-202. https://doi.org/10.1097/ 00010694-199803000-00003.

Trammell, T.L.E., Schneid, B.P., Carreiro, M.M., 2011. Forest soils adjacent to urban interstates: soil physical and chemical properties, heavy metals, disturbance legacies, and relationships with woody vegetation. Urban Ecosyst. 14:525-552. https://doi. org/10.1007/s11252-011-0194-3.

USDA-NRCS, 2003. Rock fragments volume to weight conversion chart. Exhibit 618-11. Handbook, National Soil Survey.

USDA-NRCS, d. National Soil Survey Handbook, Title 430-VIhttp://www.nrcs.usda.gov/ wps/portal/nrcs/detail/soils/ref/?cid=nrcs142p2_054242 (accessed day month year).

Vasenev, V., Kuzyakov, Y., 2017. Urban soils as hotspots of anthropogenic carbon accumulation: review of stocks, mechanisms and factors. Presented at the EGU General Assembly Conference Abstracts (p. 5537).

Vasenev, V.I., Stoorvogel, J.J., Vasenev, I.I., Valentini, R., 2014. How to map soil organic carbon stocks in highly urbanized regions? Geoderma 226-227:103-115. https://doi. org/10.1016/j.geoderma.2014.03.007.

Wei, Z.-Q., Wu, S.-H., Yan, X., Zhou, S.-L., 2014a. Density and stability of soil organic carbon beneath impervious surfaces in urban areas. PLoS One 9, e109380.

Wei, Z.-Q., Wu, S.-H., Zhou, S.-L., Li, J.-T., Zhao, Q.-G., 2014b. Soil organic carbon transformation and related properties in urban soil under impervious surfaces. Pedosphere 1 (005).

Yan, Y., Kuang, W., Zhang, C., Chen, C., 2015. Impacts of impervious surface expansion on soil organic carbon-a spatially explicit study. Sci. Rep. 5. 